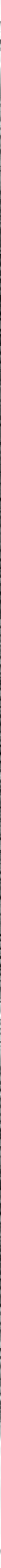



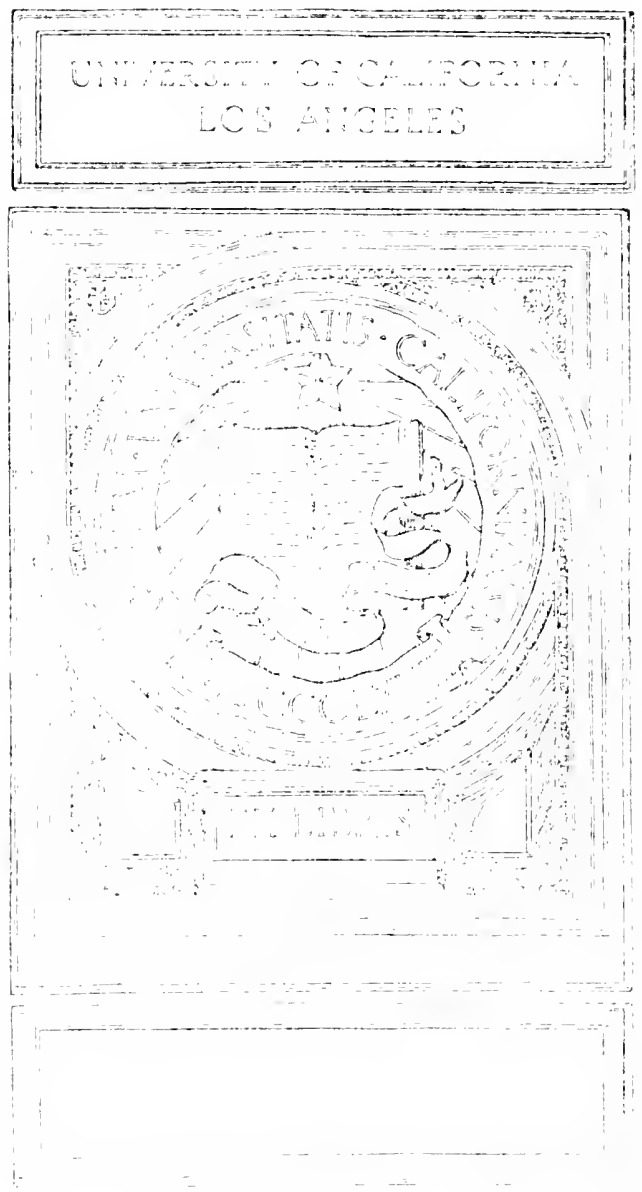
Digitized by the Internet Archive in 2007 with funding from Microsoft Corporation 



Reminiscences of Chicago

During the Forties

and Fifties 




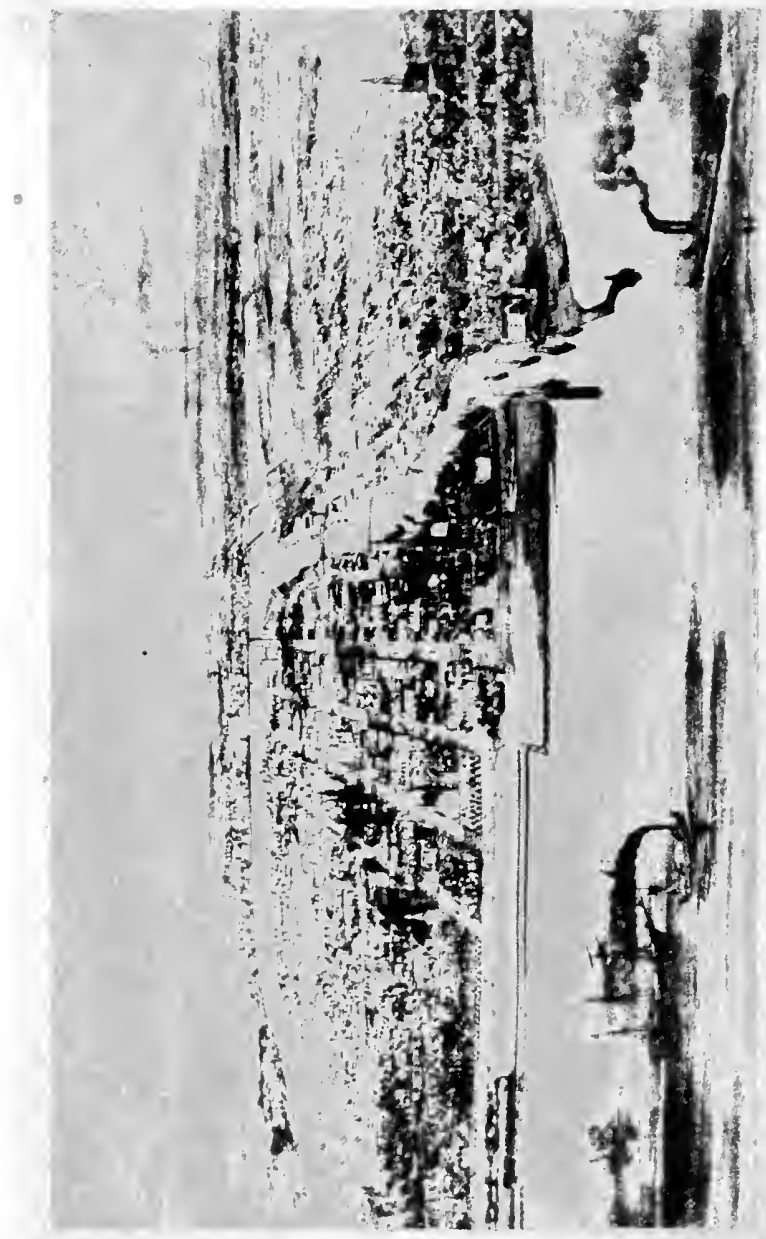



$m$
0
0
-
2
0
0
4
4
$I$
0 


\title{
The Lakesíde Classícs \\ Reminiscences \\ of Chicago During the Forties and Fifties
}

\author{
WITH AN INTRODUCTION \\ BY \\ MABEL MCILVAINE
}

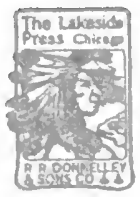

Che Zafiesioe press, Chicano

R. R. DONNELLEY \& SONS COMPANY CHRISTMAS, MCMXIII 



\section{Fublígherg}

HOLLOWING the practice of the last two seasons, the Publishers have chosen as the subject for this year's volume of the Lakeside Classics additional material concerning the earlier days in Chicago. In this volume they have confined themselves to the forties and fifties - to that period between the days of the first settlers and the outbreak of the Civil War, when the early pioneers were working out their fortunes and establishing the young, growing city as the commercial center of the Great West.

In the selections by Charles Cleaver, Lieutenant-Governor William Bross, and Joseph Jefferson there is the intimate personal touch so delight ful in all reminiscences. But a review of this period of Chicago's growth, no matter how cursory, must place emphasis upon the beginnings of that railroad system which has made Chicago the greatest railroad center of the entire world. The meeting in Chicago of all the early railroad lines from the East, the South, and the West made Chicago the great distributing point for the fast developing Mississippi Valley and enabled Chicago to forge ahead of her two rivals, Cincinnati and r St. Louis. The first railroad built out of

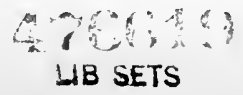




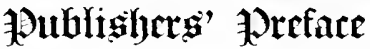

Chicago was the Galena and Chicago, now the Galena Division of the Chicago \& Northwestern Railroad. Within a year or so the Illinois Central was built into the city from the South. As these two railways were the first and were projected by Illinois enterprise, the publishers have considered them the most typical and interesting in comnection with early Chicago history. It is regretted that it has been impossible to find original letters or articles by the railroad pioneers themselves, giving a comprehensive story of the early days of railroad building. The account here reprinted has been taken from Andraes's "History of Chicago," and it is hopect that what these descriptions may lack in personalities will be more than compensated by the interest of the subject matter itself.

The Publishers again desire to acknowledge their appreciation of the work of Miss McIlvaine in searching out from the mass of material collected in the library of the Chicago Historical Society the subject matter of this volume, and also their appreciation of the courtesy of The Century Company in permitting the reprinting of a chapter from "The Autobiography of Joseph Jefferson."

It is hoped that this volume will continue to fuliill the molest mission of the Lakesicle Classics-to prove that a book can be grood and "booky" even if manufactured economically, to bear witness of the thoroughness of the 


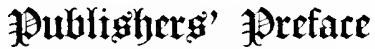

instruction and permanency of The School for Apprentices of the Lakeside Press, and to carry to all the patrons and friends of the Press at this season of good wishes, the good wishes of

\section{THE PUBLISHERS.}

Christmas, igi 3 . 



\section{Contcuts}

INTRODUCTION . . . . . . . . . XIii

William Bross . . . . . . . . I

Extracted from "What I Remember of

Early Chicago," a Lecture delivered by William Bross, Ex-Lieutenant-Governor of Illinois, at McCormick Hall, January 23,1876 .

Charles Cleaver . . . . . . . 39

Extracts from articles which appeared first in The Chicago Tribune.

Joseph Jefferson, Chicagoan . . 77

Reprinted from "The Autobiography of Joseph Jefferson."

Chicago’s First Railroad Systems 93

Reprinted from Andraes's "History of Chicago." 

Introduction 



\section{$\exists \mathfrak{n t r o d u c t i o n}$}

$7 \mathrm{HE}$ period of the Forties and Fifties in Chicago may be briefly characterized as the era of "the iron horse and mechanical man."' The advent of railroads and reapers marked the end of isolation and of primitive agriculture. Not less real in their effect upon the future of Chicago was the inauguration of commercial journalism and the establishment of a permanent theater. Between the years I 840 and 1860 the population of Chicago increased 835 per cent. Who shall say which agency did more to make life seem desirable in Chicago - the railroad, the reaper, the newspaper, or the theater?

It is not our province to attempt an answer to this question, but to place before the reader certain facts and documents from which he may draw his own conclusions. For access to all of this material, as well as to many unpublished letters, and for the privilege of producing in print the Centennial Ode of Joseph Jefferson, we are indebted to the Chicago Historical Society.

Mention has been made of reapers in connection with railroads. A fact not commonly realized is that when Cyrus $\mathrm{H}$. McCormick had decided upon Chicago as the place to xiri 


\section{Fintroduction}

build his reaper factory, it was William $B$. Ogden, Chicago's first mayor, who, in I 848 , for the space of a year, became his partner, and financially furthered the enterprise so advantageous to the (levelopment of agriculture and hence of all other enterprises in the West. The factory stood on the site of the old Kinzie House, on Kinzie Street near the Rush Street bridge. It is notable that the first railroad out of Chicago started on the line of Kinzie Street, running west, in I848. That was the Galena and Chicago Union Road, of which Mr. Ogden was first president, and of which he prophesied in his first report that it would become the nucleus of the Northwestern system. An anecdote related to the writer by a neighbor, whose father was financial manager for Mr. Ogden, illustrates the difference between a railroad magnate then and now. It became the duty of $\mathrm{Mr}$. Quigg, the aforesaicl financial man, to ascertain the full amount of Mr. Ogden's wealth. After a long investigation he announced that it was about a million dollars. "My God, Quigg, but that's a lot of money!" cried Mr. Ogden.

Just prior to the coming of railroads, the Illinois and Michigan Canal had seemed the all-important thing. Of this we have heard in the previous volume of this series. At the very time when railroals were about to revolutionize the entire question of transportation, the stage lines ruming to and from Chicago 


\section{Introduction}

formed a colossal (!) combination, under the name of Frink \& Walker. These stages kept up an intermittent contact with the neighboring states, and, starting from an old shanty which stood where the Merchants' Loan \& Trust Company now is, embraced in their itinerary some two thousand miles. As late as I 847 measures were being put through the legislature for the laying of plank roads, and every effort was made to evade "the iron horse"' as long as possible. Within the city there was not a single paved street, and clrays were frequently abandoned in the downtown district, as impossible of recovery from the mud. From March until the first of May the city was practically cut off from communication with the world by reason of the mud, and, as there was no telegraph, news from New York was sometimes a month in reaching us by the overland route.

To the relief of this beleaguered city came at last a champion armed with a pen-William Bross, who, born in New Jersey in I 8 I 3, settled in Chicago in 1848 , iclentifying himself first with the book-trade, and afterwards with The Democratic Press and The Chicago Tribune. For many years he made it his business to chronicle the state of Chicago's advancement, to clrop hints at home as to possible improvements, and to issue an annual statement to the world at large, but not on the subject of our 


\section{Introduction}

shortcomings. "Deacon" Bross, as he was commonly called, was a member of the Second Presbyterian Church. In fact it was sometimes designated as "Deacon Bross's Church.", "Deacon" Bross was also an Abolitionist, long before that was a popular thing to be, and when the Republican party was formed in I 854 it was "Deacon" Bross who macle the speech in Dearborn Park nominating Fremont for president. "Deacon" Bross proceeded with his double mission of blowing the horn of Chicago's commercial prosperity and sounding the last trump for the loom of slavery until, the war being ended, he was raised to the office of lieutenant-governor of Illinois. In this capacity, as presiding officer of the Senate in Illinois, when the constitutional amendment for the abolition of slavery in the United States was presented to the several states for ratification, his name led all the rest of signatures affixed to that charter of human rights. Finally, when, with Vice-President Colfax, he visited the Rocky Mountains in I 868, and had ascended Mount Lincoln, a neighboring peak was pointed out by the miners thereabout, a peak only a little lower than Mount Lincoln, and if to-day you should ask the name of it you would learn that it bears the name of Bross. Hon. William Bross, Presbyterian, Republican, Lieutenantgrovernor of Illinois, and Founder of Commercial Journalism in Chicago, has left us a priceless legacy in the form of a lecture entitled What $I$ 


\section{Introduction}

Remember of Early Chicago. It was delivered in McCormick Hall and was reported in The Chicago Tribune of 1876 . This is here reprinted in full.

Charles Cleaver, Chicago's “Original Soap-fat Man," Tallow Chandler, Founder of Cleaverville, and all-round observer, in his Early Chicago Reminiscences, has given an invaluable account of things in general in Chicago and the packing industry in particular, dating from I 833 to about 1857 . Of this we reprint the portion dealing with the Forties and Fifties. Mr. Cleaver, born at Kensington Common, London, England, in 1814 , came to Chicago in I833, and lived until I893. Having allied himself with the various packers of Chicago as a sort of clearing-house for lard, his fortune was sufficiently large in 1857 to allow him to retire from the office of chief "Renderer," and to enter upon that of real estate dealer. His house, erected in 1853 near the foot of 38 th Street, became the nucleus of a suburban town named Cleaverville. With true feudal instinct he promoted the welfare of his tenants, even to the extent of building a church for them (the first church in Hyde Park), of floating houses down the river for their accommodation when none were to be found near by, and finally, when the Illinois Central was creeping toward Chicago he paid them $\$ 3800$ a year to run trains to his settlement. He was one of the organizers 


\section{Futroduction}

of Dearborn Seminary, and held the high honor of membership in the old Hook and Ladder Company No. I, that noble little group of men, including Silas Cobb, P. F. W. Peck, and others, who used to run to the fires, dragging their engine after them, in the Forties and Fifties.

"Joseph Jefferson, Actor" (as his name appeared in the first directory of Chicago), has told in his Autobiography the story of the first real theater in Chicago, and has, in the telling, vividly depicted Chicago at the beginning of the epoch in question.

Joseph Jefferson the younger, although we claim him as a Chicagoan, was born in Philadelphia, February 20th, I829. At the time that he first saw Chicago, just before the Forties, he could not have been more than ten years old, but since he was already holding the audience between the acts with comic songs, and "cloing" a Roman Senator, in Julius Caesa), he must have been rather more than an “infant phenomenon." His father, Joseph Jefferson the elder, was an actor of experience, and his mother a lady of much grace and refinement, as well as an accomplished actress. No one that has ever written of Chicago has more truly callght the spirit of the place and time than has Joe Jefferson, in the breezy sketch here given. Not only had he the actor's faculty for "taking in the scone," but the xviii 


\section{Fintraduction}

painter's ability to clepict it so that others might see it. Who but Joe Jefferson ever told us about the "busy little town," with its "bright and muddy streets," "gaudy-colored calicoes,", "blue and red striped ticking," "'bar-rooms, real-estate offices," and oceans of "attorneysat-law"? Who ever macle us hear the "Saw! saw! bang! bang!" of "the buildings going up, and the sidewalks going down?" It is right that his name should appear in the Chicago Directory of that year, together with that of his father. If he were not a Chicagoan by birth, he was one by election.

The elder Jefferson had come to Chicago to found a theater, in company with his brotherin-law, Alexander McKenzie, who already resided here. Prior to the coming of the Jeffersons, Chicago's dramatic endeavors had taken place in the abandoned Sauganash, Mark Beaubien's old hotel, where Messrs. Isherwood and McKenzie had given sporadic performances. Haring obtained the privilege of using, for theatrical purposes, the one-time auctionhouse called the Rialto, Mr. McKenzie had induced the Jefferson family to come and iraugurate the enterprise under the name of "The Chicago Theater." They opened with The Lati of Lyons, with Master Joseph Jefferson singing the comic song of Lord Lowel and Lady I anc. Jefferson the elder was manager.

Mr. Samuel Beach fifty years later wrote of this company: "Without the aid of the gilcled xix 


\section{Introduction}

surroundings . . that are the common actjuncts of the modern stage, our pioneers were forced to rely solely upon the sterling merit of each actor. . . The delicate shades and lights of life were touched by master hands. . . . The purpose was to place the theater among the honored institutions of our enlarging civilization."'

Writing to J. H. McVicker on Christmas Day, I882, Joseph Jefferson, Jr., said of this occasion: "The new theater was quite the pride of the city, and the idol of the manager; for it had one tier of boxes and a gallery at the back. I don't think the seats of the dresscircle were stuffed, but I am almost sure they were planed. . . The city hack then from three to four thousand inhabitants; I can remember following my father along the shore, when he went hunting on what is now Michigan Avenue."

John B. Rice founded his theater in 1847 , and James $H$. McVicker built McVicker's Theater in 1857 . In that same year the younger Jefferson was appearing with Laura Keane in New York. Our Amrialn Cousin had a run of 140 nights. In 1860 he sailed for England, and with Dion Boncicault recast Rip Van Irinkle, which, as he tells us, he had first conceived, as a play, in the barn at his summer home. We all know the story of his trimmph in that rôle, as well as in lime $M C$ Fire Shillings and The Rizals. In I 892 Yale 


\section{Fntroduction}

College conferred upon him the degree of Master of Arts.

In a lecture on art which he gave in a Chicago studio, in 1903 , the writer heard Joe Jefferson explain the difficulty of the actor's art, in that the effect must be instantaneous. No opportunity is given to rub out and begin over, as in painting. He also told how difficult it is, after one has played a part many times, to appear surprised when addressed by one of the other actors, and, to illustrate, he got down on the floor, without accessories, and, performed the awakening scene from Rip Van Winkle. So perfect was the illusion created that when it was over one was amazed to see standing there a man of modern time, clad in the garments of to-day, and not the tattered old man of the mountain, arising crippled with age and haunted by voices of a former generation.

In his Autobiography Jefferson tells that after reading Irving's story, he began to put together the play of Rip Ian Winkle by buying a wig. Then he practiced before a glass, until the neighbors thought that he had a lunatic housed within. He had since learned to do the part without the wig, and even with the distracting influence of a pair of rather bright blue trousers, a yellow waistcoat, black Prince Albert, and red necktie.

The writer's grandfather once met him in a little town in Ohio when he was dressed so oddly that the hotel clerk was refusing him a 


\section{Tutroduttion}

room. Upon the clerk's being assured that he was a friend of grandfather's, and was only joking about requiring a room by himself, Jefferson was asked to sign the register, which he did in a hand like that of John Hancock, instantly accepting the hospitality of a total stranger, on the ground that they both came from Chicago! As a matter of fact Jefferson was out of money, and grandfather paid the bill.

The Chicago Historical Society possesses a manuscript poem from Jefferson's pen entitled Centennial Ode. It was read by the veteran actor on October I, 1903, in the Auditorium Hotel on the occasion of the mayor's banquet celebrating the one hundredth anniversary of the building of Fort Dearborn. By permission of the officers of the society it is reproduced here for the first time.

\section{CENTENNIAL ODE}

All hail to Chicago! We greet you to-night

On the eve of your hundreth year.

May our spirits be cheerful, convivial, and bright, May our smiles chase away every tear.

I knew your great city when I was a boy,

As a man I have witnessed its progress with joy.

Its early achievements had startled this nation,

And then came the blow of its sad desolation.

But she rose like a Phoenix, and spreading her wings Sheltered statesmen and merchants like princes and kings.

Her watchword was "Onward" from every heart, In science, in commerce, religion and art.

She conquered distatir-aye, that was the test -And gained her true title, "The Pride of the West." xxii 


\section{Introduttion}

Capt. A. T. Andreas, in his monumental History of Chicaso, Volume I, has recounted the early annals of Chicago's railroad systems in a manner so complete as to need no further comment here. From this we have made liberal selection for the last article in this volume.

Mabel Mcilvaine. 

Reminiscences of Chicago During the Forties and Fifties 



\section{Zmilliam 2 zrogs}

[Extracted from "What I Remember of Early Chicago," a Lecture delivered by William Bross, Ex-Lieutenant-Governor of Illinois, at McCormick Hall, January 23, I876.]

NHE charter of the city of Chicago bears date March 4, 1837, and the first election for city officers was held on the first Tuesday in May, I837. Not a few of the men and women who saw it when an Indian trading post, with Fort Dearborn to defend the settlers, are still among us, and the ladies certainly would not feel complimented were they called old. Hence whatever is said about "The Early Times in Chicago" must be regarded as relative, for the city had not yet numbered thirty-eight years. As I first saw Chicago in October, 1846 , and commenced my permanent residence here on the 12 th of May, I848, I can scarcely be called an old citizen, and yet in that time it has grown from a city of about 18 , ooo (later in the season the census gave us 20,023) to nearly, if not quite, 450,000 - an increase never before equaled by any city in the history of the world. From a city then scarcely ever mentioned, she has become fourth in rank and population upon the American Continent. 


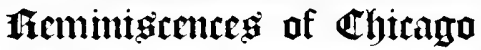

But granting for the moment that I am an old citizen, I recognize the duty of placing on record-as myself and others have doubtless often been urged to do - what I know personally of the history of Chicago. Though this may require a too frequent use of the personal pronoun, your Directors are responsible if I bore you with it. If each citizen would clo it, the future historian could select what best suited his purpose, and Chicago would have what no other city has, a history from its earliest times, written by its living inhabitants. In I 854 I prepared and published some notes on the history of the Town of Chicago - in fact, going back to the discovery of the site by the French Jesuit missionaries, Marquette and Joliet,- - and I shall devote the hour to giving you a supplement to what used to be called "Our Pamphlet"' of 1854. This was ably continued by my friend, Elias Colbert, in I868; but neither of them pretends to give much of how Chicago appeared to the visitor in the "earlier times" of its history.

Your speaker, as above stated, first arrived in Chicago early in the morning of the second Sabbath in October, I846, now of course nearly thirty years ago. We landed from the steamer Oregron, Captain Cotton, near the foot of Wabash Avenue, and, with others, valise in hand, trudged through the sand to the American Temperance House, then situated on the northwest comer of Wabash Avenue and Lake 


\section{ZHilfiam 20rati}

Street. Soon after breakfast a tall young man, made apparently taller by a cloth cloak in which his gaunt figure seemed in danger of losing itself, and whose reserved, modest manners were the very reverse of what we had expected to find at the West, called on the clergy of our party and invited one of them to preach and the rest of us to attend service in the Second Presbyterian Church. That cloak would now be well filled by its owner, the Rev. Dr. Patterson, who has grown physically as well as intellectually and morally with the growth of the city, to whose moral welfare he has so largely contributed. Of course we all went to what by courtesy, as we thought, was called a church. It was a one-story, balloon, shanty-like structure that had been patched out at one end to meet the wants of the increasing congregation. It stood on Randolph Street, south side, a little east of Clark. It certainly gave no promise of the antique but splendid church that before the fire stood on the corner of Washington Street and Wabash Avenue, or that still more elaborate and costly building, the Rev. Dr. Gibson's church, at the corner of Michigan Avenue and Twentieth Street.

That afternoon and Monday morning afforded ample time to see the city. The residence portion of it was mainly between Randolph and Madison streets, and there were some scattered houses as far south as Van Buren, on the South Side, four or five blocks north of 


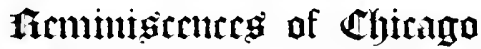

the river on the North Side, with scattering residences about as far on the West Side. There were perhaps half a clozen or more wooken warehouses along the river on Water Street. The few stores that pretended to be wholesale were on Water Street, and the retail trade was exclusively done on Lake Street. Stores and dwellings were, with few exceptions, built in the balloon fashion. To some of my hearers this style of building may already be mysterious. Posts were placed in the ground at the corners, and at proper distances between them blocks were laid down singly or in cobhouse fashion. On these foundations were laid, and to these were spiked, standing on end, $3 \times 4$ scantling. On these sheathboards were nailed, and weatherboards on the outside of them; and lath and plaster inside, with the roof, completed the dwelling or store. This cheap, but for a new town, excellent, mode of building, it is claimed, was first introduced, or, if you please, invented, in Chicago, and I believe the claim to be true. Of course the fire made sad havoc with them at times; but the loss was comparatively small, and they were quickly and cheaply rebuilt. True, Chicago was ridiculed as a slab city; but, if not pleasant, to bear ridicule breaks no bones. When our merchants and capitalists had grown rich enough to build permanent buildings, of course they did it. Then there were not as many bricks laich in walls in the whole city as there 


\section{Zyifliam $2 \mathfrak{b r o g i g ~}$}

are now in single blocks anywhere near the business center of the city. Chicago need not shrink from comparing them with those in any other city upon the continent.

My first objective point in northern Illinois was Batavia, on Fox River, forty miles distant, where some Orange County (N. Y.) friends resided. As Frink \& Walker's stages did not pass through the town except on the road along the river, the problem was how to get there. The streets were full of farmers' teams, and in half an hour's tour among them we found a man who, for a small sum, agreed to land us there Monday evening. It was nearly noon before we got started, and as two of my traveling companions lived three or four miles west of Fox River, and were bound to get home that night, they soon began to use all their arts to urge our Jehu onward. At the old tavern on the west side of the Aux Plaines, near the bridge, they treated the old farmer freely, and again at Cottage Hill, Babcock's Grove, and other places; but sooth to say, the whisky, though it had a marked effect upon the old man, must then, as now, have been "crooked," for the more he got of it inside of his vest the slower he stubbornly determined to drive his team; but he assured us he would "root along" and get to Batavia that evening, and he did. Of course, an account of my journey to St. Louis and up the Ohio homeward has no place in this lecture. 


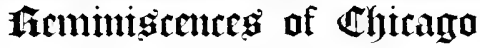

As a specimen of traveling in I 848 , I mention that it took us nearly a week to come from New York to Chicago. Our trip was made by steamer to Albany; railway cars at a slow pace to Buffalo; by the steamer Canada thence to Detroit; and by the Michigan Central Railway, most of the way on strap rail, to Kalamazoo; here the line encled, and, arriving about eight o'clock in the evening, after a good supper, we started about ten in a sort of a cross between a coach and a lumber box-wagon for St. Joseph. The road was exceedingly rough, and, with bangs and bruises all over our bodies, towards morning several of us left the coach and walked on, very easily keeping ahead. In this tramp I made the acquaintance of John S. Wright, then, and for many years afterward, one of the most enterprising and valuable citizens Chicago ever had. He gave me a cordial welcome and a great deal of valuable information. On Sabbath he called and took me to church, and embraced many opportunities to introduce me to Mayor Woodworth and other leading citizens, giving me a lesson in courtesy to strangers which I have never forgotten. I beg to impress it upon you all as a duty too much neglected in the hurry and bustle that surrounds us on every side.

The steamer Sim IVard, with Captain Clement first officer, and jolly Dick Somers as steward, afterwards Alderman, brought us to the city on the evening of the 12 th of May, 


\section{Zilliam $\mathfrak{B r a g k}$}

I 848, and here, at I 2 I Lake Street, with Dr. Scammon's drug-store on one side and Lock's clothing store on the other, the stranger from the East settled down quietly as a bookseller. The city had added four thousand to its population in the year and a half after I first saw it; but it had changed very little in appearance. It was still pre-eminently a slab city. The Illinois and Michigan Canal had been opened the month before, and during the summer packets were put on, and, running in connection with steamers on the Illinois River, quite an impetus was given to travel through the city. To them it did not present a very inviting aspect. The balloon buildings above spoken of were mostly dingy and weather-beaten. The only two stone buildings in the city, built of blue limestone brought as ballast from the lower lakes, stood on Michigan Avenue between Lake and South Water streets, on the site now occupied by the Illinois Central Railroad offices. They were the aristocratic mansions of the city. There were a few brick residences and stores, but these were the exception. It was curious to notice how long some of the old balloon buildings would escape the fire. The old store in which Mosely \& McCord commenced business, between Clark and La Salle streets, on the north side of Lake, was built when the proprietors could look south to Blue Island with not a building in front to obstruct the view. There it stood, with the 


\section{fremintwernes of $\mathbb{C h i t a g a}$}

sign "Mosely \& McCord" just below the roof, till it was all surrounded by brick buildings, and the insurance on it has cost ten times what the building was ever worth. Subtract the few scattering brick buildings on South Clark Street, in the vicinity of Twelfth Street, and the dingy shanties in that vicinity on Clark Street and Third and Fourth avenues will best represent what most of Chicago was in 1848 .

And here I may as well mention the sources from which our fine building materials are derived. Till after that year it was supposed that we had no good rock for building anywhere near the city. The blue-limestone quarries from which the stone for the two dwellings above mentioned was taken, were thought to be our best and cheapest source of supply. Besides these, there had been brought from the lower lakes some sandstone flagging. It lay in front of the Laflin residence block, corner of Washington Street and Michigan Avenue, where it served for a sidewalk up to the time of the fire in $187 \mathrm{I}$. Discussions, held for a long time by the trustees of the Second Presbyterian Society, when it was proposed to build a new church edifice in 1849 , resulted in their cletermining to use stone found near the western limits of the city. The location has become somewhat famous as the site of our first artesian well. The rock is a porous limestone, with sufficient silex mixed with it to make it very hard. It seems to have been 


\section{Z̈illiam $2 \mathfrak{B r a g i g}$}

formed under a bed of bitumen, or coal, for the pores in the rock are filled with it, and hence some of the less porous stones in the church were of a pale creamy color, while others were so filled with pitch or bitumen that it oozed out in hot weather, and they were as black as tar. Hence it was called the speckled or spotted church, a name which, referring to an unfortunate occurrence in its after history, my friend Sam Bowles said was derived from its speckled morality. The same rock was used in rebuilding the church at the corner of Twentieth Street and Michigan Avenue. The use of this rock was really the first important event of the kind in the building history of the city.

While this material was regarded as a most excellent one for church purposes, giving them an antique and venerable appearance, it was not considered the thing for the Cook. County Courthouse in 1852 or ' 53 - I did not have time in this, as in some other cases, to look up the exact date. Our wise men of that ancient period, after due deliberation, determined to use a rock found at Lockport, New York, a bluish-colored limestone. Fortunate it was that official plundering had not then, as now, been reduced to a science, or the entire county would have been forever swamped in the debt contracted for the money to build it. This was regarded as the cheapest and best rock that could be had for building - for such 


\section{fremintitenteg of $\mathbb{C h i t a g o}$}

structures - and was the second really progressive step in the building of the city.

During all this time it is remarkable that no one had thought of the limestone quarries through which the canal had been cut for several miles this side of Lockport. The reason probably was that some of the strata were not well crystallized and rotted readily; but tens of thousands of cords of it that showed no signs of decay lay scattered along the canal. In 1852 or 1853 some one, if I mistake not, ex-Mayor Sherman, built a store on Randolph Street,-it was afterwards removed to Clark Street opposite the Courthouse,-facing it with this stone. Everybody was delighted with its beautiful color. It was found to become very hard when seasoned, and pronounced a marble by President Hitchcock, of Amherst College. It very soon came into general use. In December, I853, the Illinois Stone and Lime Company was formed, with A. S. Sherman, now of Waukegan, as its efficient manager. The next summer, Harry Newhall built two very fine dwellings of it on Michigan Avenue between Adams and Jackson streets, and M. D. Gilman followed with another next to Newhall, and after that its use became general. It is conceded to be one of the best and most beautiful building materials in the world. Cheaply quarried and easily accessible by water, Chicago owes much of her prestige and prosperity to these Athens 


\section{Zmifliam $\mathfrak{2 r o g g}$}

marble quarries. From it also Chicago constructs the best sidewalks in the world, for, resting on an inner and outer wall, they are unaffected by frost, and are always smooth and pleasant to the pedestrian. Before, and especially since the fire, Chicago has drawn upon the beautiful sandstone quarries of Ohio; the red sandstone of Connecticut and of Lake Superior; she has cheap access to the marble deposits and the granite of Vermont, Massachusetts, and Minnesota, I 50 miles west of the head of Lake Superior, and it is now conceded that no city in the world has a better variety of building material or is making a more judicious and liberal use of it.

Going back to 1848 , after remaining a week at the City Hotel, corner of State and Lake streets, I was admitted to a most excellent home, that of the late Rev. Ira M. Weed, corner of Madison and State streets, where Buck \& Rayner's drug-store now is. This was considered far south, and as the sidewalks were not all good, the best that could be found was south on Dearborn to Madison, where a very large sign on a paintshop, where the Bank of Commerce now is and directly opposite the Tribune office, reminded me to turn eastward. The sidewalks, where such luxuries were indulged in, lay in most cases upon the rich prairie soil, for the stringpieces of scantling, to which the planks were originally spiked, would soon sink down into the mud after a 


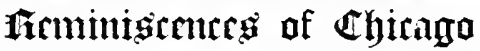

rain, and then as one walked, the green and black slime would gush up between the cracks to the great benefit of retailers of blacking. One's clisgust can be understood when it is stated that this meant some minutes of active personal service in the morning, for this was long beforc the professional bootblack was born-certainly before he makle his advent in Chicago.

In March, r849,- -I think March was the month, - my family having arrived per steamer Niagara the August previous, we commenced housckeeping on Wabash Avcnue betwcen Adams and Jackson streets, in a cozy little house at the modest rent of twelve clollars per month. In May following I bought of Juclge Jesse B. Thomas forty feet on Michigan Avenue, commencing eighty feet south of the corner of Van Buren Street, for \$I,250. The Judge had bought it at the canal sales in the spring of 1848 for $\$ 800$, on canal time; viz.,-as Dr. Egan afterward directed in taking his pills, - one-quarter down, balance in one, two and thrce years. I paid the Judge his profit and what he had advanced on the first payment, and assumed the balance due the canal trustees, and took the deed to me directly from them. It was in a safe place during the fire, and of course is now a very ancient document. In the fall of I849 I bought a small wood house that $I$ found moving along on Wabash Avenue, and moved 


\section{Zmifliam $2 \mathfrak{b r a g g}$}

it on my lot. In this modest home we spent some six very happy years. Judge Manierre lived on Michigan Avenue, corner of Jackson Street, where the Gardner House now is. Harry Newhall lived on the block north. Mine was the only house on block nine, except a small tenement on the rear of a neighboring lot, where lived an African friend and brother named William. There were at first no sidewalks for a considerable distance north, and hence we were not troubled with promenaders on the avenue. The lake shore was perhaps a hundred feet east of the street. There my brother John and myself, rising early in the morning, bathed in summer for two or three years. We had an excellent cow-for we virtually lived in the country-that, contrary to all clomestic propriety, would sometimes wander away, and I usually found her out on the prairie in the vicinity of Twelfth Street. I saw a wolf run by my house as late as I 850 . An incident in the purchase of the lot will illustrate the loneliness of our situation. The rule of the speculators at the canal sales was to buy all the property on which the speculator could make the first payment, and then sell enough each year to make the others. Judge Thomas had followed this plan, and advertised a large list of property in the spring of 1849 . He sold to myself and the Rev. Dr. Patterson adjoining lots at $\$ 1,250$ at private sale; but it was agreed that these should be sold with the 


\section{fimmintente of Elyitago}

rest, so as to attract customers, as Michigan Avenue had become somewhat popular as a prospective place of resiclence. When my lot was struck off to me for $\$ 1,300$, Harry Newhall came across the room, and said, "Bross, did you buy that lot to live on? Are you going to improve it?" "Yes," was the reply. "Well," said he, "I'm glad of it; I'm glad some one is going to live beyond me. It won't be so lonesome if we can see somebody going by night and morning." We then lived, as above stated, on Wabash Avenue, between Adams and Jackson streets.

In the winter of $1851-52 \mathrm{my}$ friend, the late Charles Starkweather, insisted on selling me fourteen acres of land immediately south of Twrenty-sixth Street, and east of State to Michigan Avenue. Captain Clement and myself went out of town to look at it, going across lots south of Twelfth Street. It was away out on the prairie, and I made up my mind that the price ( $\$ 500$ per acre) was too much. I could raise the $\$ 1,000$ to make the first payment; but where was the six per cent on the balance for the next ten years to come from? Captain Clement took the property, paid the $\$ 1,000$, and, in seven months, sold it for $\$ 1,000$ an acre, clearing in that time $\$ 7,000$ on an investment of $\$ I, 000$. But the Captain let a fortune slip through his hands, for that fourteen acres is now valued by James $\mathrm{H}$. Reese, Esq., at $\$ 560,000$, or $\$ 40,000$ per 


\section{Z\#illiam $2 \mathfrak{B r a g g}$}

acre. In that case, as in scores of others, I too just escaped getting rich; but I have an abundance of good company, for hundreds of my fellow-citizens have missed opportunities equally good.

Take the following instances: Walter $\mathrm{L}$. Newberry bought the forty acres that form his addition to Chicago, of Thomas Hartzell, in 1833 , for $\$ 1,062$. It is now valued at $\$ 1,000,000$. Major Kingsbury had been off on an exploring expedition about this time, till his pay as an army officer, above his immediate necessities, amounted to some six hundred dollars. A brother officer advised him to salt this down for his two children. He bought for it I60x I 80 feet corner of Clark and Randolph streets, and twenty-seven acres on the North Branch. It is now worth from $\$ 600,000$ to $\$ 1,000,000$. One quick at figures could probably show that at compound interest the cost of the land would have realized much more than it is now worth. In time this certainly will be true; but if the rents of the land are taken in place of the interest, let him who has time to make the figures determine what would have been the more profitable investment.

I said we had no pavements in 1848 . The streets were simply thrown up as country roads. In the spring, for weeks, portions of them would be impassable. I have at different times seen empty wagons and drays stuck on Lake and Water streets on every block between 


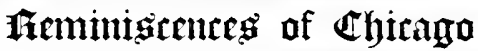

Wabash Avenue and the river. Of course there was little or no business doing, for the people of the city could not get about much, and the people of the country could not get in to do it. As the clerks had nothing to do, they would exercise their wits by putting boards from dry goods boxes in the holes where the last dray was dug out, with significant signs, as, "No Bottom Here," "The Shortest Road to China." Sometimes one board would be nailed across another, and an old hat and coat fixed on it, with the notice "'On His Way to the Lower Regions." In fact, there was no end to the fun; and jokes of the boys of that day-some were of larger growth-were without number.

Our first effort at paving, or one of the first, was to dig down Lake Street to nearly or quite on a level with the lake, and then plank it. It was supposed that the sewage would settle in the gutters and be carried off, but the experiment was a disastrous failure, for the stench at once became intolerable. The street was then filled up, and the Common Council established a grade from two to six or eight feet above the natural level of the soil. This required the streets to be filled up, and for a year or two Chicago lived mostly on jackscrews, for the buildings had to be raised as well as the streets. Until all the sidewalks were raised to grade, people had to go up and down stairs from four to half a dozen steps 


\section{Zmilfiam $\mathfrak{D r a g g}$}

two or three times in passing a single block. A Buffalo paper got off a note on us to the effect that one of her citizens going along the street was seen to run up and down every pair of cellar stairs he could find. A friend asking after his sanity, was told that the walkist was all right, but that he had been in Chicago a week, and, in traveling our streets, had got so accustomed to going up and down stairs that he got the springhalt and could not help it.

The Court-house Square should not be forgotten. On the northwest corner of it stood, till long after I848, the Jail, built "of logs firmly bolted together," as the account has it. It was not half large enough to hold the aldermen that, if standing now, ought to be in it, not to speak of the Whisky Ring, and certainly it was not strong enough to keep them there. The Courthouse stood on the northeast corner of the Square - a two-story building of brick, I think, with offices in the lower story. They stood there until I853, when they where torn down to give place to the new building completed in that year.

I said we had no gas when I first came to the city. It was first turned on and the town lighted in September, I850. Till then we had to grope on in the clark, or use lanterns. Not till I 853 or ' 54 did the pipes reach my house, No. $2 \mathrm{O} 2$ Michigan Avenue.

But the more important element, water, and its supply to the city, have a curious history. 


\section{fitmintätometg of êthitago}

In I 848, Lake and Water, and perhaps Randolph streets, and the cross streets between them east of the river, were supplied from logs. James $\mathrm{H}$. Woodworth ran a grist-mill on the north side of Lake Street near the lake, the engine for which also pumped the water into a wooden cistern that supplied the logs. Whenever the lake was rough the water was excessively muddy, but in this myself and family had no personal interest, for we lived outside of the water supply. Wells were in most cases tabooed, for the water was bad, and we, in common with perhaps a majority of our fellow-citizens, were forced to buy our water by the bucket or the barrel from water-carts. This we dicl for six years, and it was not till the early part of 1854 that water was supplied to the houses from the new works upon the North Sicle. But our troubles were by no means endecl. The water was pumped from the lake shore the same as in the old works, and hence, in storms, it was still excessively mudcly. In the spring and early summer it was impossible to keep the young fish out of the reservoir, and it was no uncommon thing to find the unwelcome fry sporting in one's washbowl, or dead and stuck in the faucets. And besides they would find their way into the hot-water reservoir, where they would get stewed up into a very nauseous fish chowder. The water at such times was not the only horror of all good housewives, but it was justly 


\section{Zilliam 2 rogg}

thought to be very unhealthy. And, worse than all this, while at ordinary times there is a slight current on the lake shore south, and the water, though often muddy and sometimes fishy, was comparatively good, when the wind blew strongly from the south, often for several days the current was changed, and the water from the river, made from the sewage mixed with it into an abominably filthy soup, was pumped up and distributed through the pipes alike to the poorest street gamin and to the nabobs of the city. Mind you, the summit level of the canal had not then been dug down and the lake water been turned south. The Chicago River was the source of all the most detestably filthy smells that the breezes of heaven can possibly float to disgusted olfactories. Davis' filters had an active sale, and those of us who had cisterns betook ourselves to rain-water - when filtered, about the best water one can possibly get.

As Chicago, with all her enterprise, did not attempt to stop the south wind from blowing, and her filthy water had become unendurable, it was proposed to run a tunnel under the lake to a point two miles from the shore, where the water was always pure,- one of the boldest and most valuable thoughts ever broached by a civil engineer,--but our able fellow-citizen, E. S. Chesbrough, not only planned but carried out the great enterprise to a successful conclusion. Ground was broken March I7, 


\section{fremintitenteg of Ohitaga}

1864; it was completed December 6, I866, but it was not till March 25, 1867, that the water was let in and began to be pumped into the pipes to supply the city. A few words as to the way it was constructed: In cligging uncler the city a hard blue clay is reached at the depth of a few feet. Experiments proved that this bed of hard, compact clay extended under the lake. At the foot of Chicago Avenue, where it was proposed to $\sin k$ the shore end, a bed of quicksand had to be passed through. To do this, cast-iron cylinders were procured, nine feet long. The flanges by which they were to be bolted together were on the inside, so that they could sink smoothly through the sand. These were lowered successfully, as the material from the inside was taken out, till the hardpan was reached. Brick was then used. The water two miles from shore was thirty-five feet deep. In order to start that end of the tunnel an octagonal crib was built of square timber, framed and bolted firmly together, with several water-tight compartments and a space in the center left open sufficiently large to receive the same kind of cast-iron cylinders as were used at the shore end. The crib was nearly one hundred feet in diameter, ancl, if I mistake not, fifty or sixty feet high. It was built in the harbor, and during a calm it was towed out two miles and anchored due east of Chicago Avenue; then scuttled, the compartments were filled with 


\section{ZMilliam $\mathfrak{B r a g g}$}

stones and it was imbedded firmly into the mud at the bottom of the lake. The cylinders were bolted together and forced down into the hardpan, the water was pumped out and the brickwork was fairly commenced. The shore shaft was sunk ninety feet, and then at the crib eighty-five feet, and then the workmen at each end commenced excavating and bricking up the tunnel towards each other. Of course I need not give more particulars, nor speak of the four-mile tunnel to the corner of Ashland Avenue and Twenty-second Street, where new pumping works are in process of erectionour works on the lake shore being found only capable of supplying the 450,000 people now said to be in the city. Chicago may well be proud of her water works, for they are truly splendid, and furnish her with an abundance of as pure water as can be found in any city in the world.

We had no sewers in 1848 . The first attempts were made a year or two later with oak plank, I think on Clark Street. I have no time nor space for particulars, but will only add that a thorough and effective system has been extended through all the more thickly settled portions of the city, and the deepening of the Illinois \& Michigan Canal carries the sewage down the Illinois River, and, except when ice covers the canal and river for many weeks, it does no damage whatever, and does not even make itself known by offensive odors. 


\section{Ifeminigente of ohitago}

Our mails from the East came by steamer from St. Joseph or New Buffalo, or by stage from the west end of the Michigan railways, till February 20, I852, when the Michigan Southern was opened to this city. Of course during severe storms, while navigation was open, and during the winter and spring, when the roads were about impassable, they were very irregular. Sometimes we would be a week or two without any news from the outside world. Our long winter evenings were employed in reading,- much more so than now,-in attending lectures and debates at the Mechanics' Institute, in going to church, and in social life. Chicago people have always had abundant means to employ their time fully and profitably. The postoffice stood on Clark Street, on the alley where the north side of the Sherman House now is. It had a single delivery window a foot square, opening into a room with a door on the alley, and another on Clark Street. All the city could see the flag flying from the Sherman House, when the mail steamer from the other side of the lake was signaled. Each one knew how long it would take her to reach her dock and the mails to get distributed. For a long time before the delivery winclow would open, the people would begin to assemble, the first taking his station at the window and the others forming in line through the rear door into the alley, often far into the street, like a long line of voters at 


\section{Zlifliam $2 \mathfrak{b r a g i g}$}

election. Here I saw one day an incident which I mention as a tribute to one of the best and noblest of men, and as an example for all of us to follow. At one time when we had been without mail for a week or more, I stood in the line perhaps a dozen from the window and Robert Stewart two or three ahead of me. Just as the window opened and the column began to move, a woman, poorly clad and evidently a foreigner, rushed in at the front door, and, casting her eye down that long line of men, the muscles of her face twitched and she trembled with anxiety. She evidently expected a letter from dear ones far away over the broad Atlantic. Not a word was uttered by the crowd, and there she stood, waiting in agony for the crowd to pass by, till it came to Mr. Stewart's turn. With a kindly wave of the hand he said, "Come here, my good woman," and, placing her directly in front of him, she grasped her letter, and with a suppressed "Thank the Lord and you, sir," she left, the most happy person in the crowd. Any man might do such an act for a lady in silks; but only a noble, Christian gentleman like Robert Stewart would do it for a poor, forlorn woman in calico.

There was not a railway entering the city from any direction in I 848 . Some strap rails were laid down that fall, or during the winter following, on the Galena \& Chicago, now the North Western, and in 1850 , through the 


\section{Ifomintwatents of ethirago}

personal endorsement of ex-Mayor B. W. Raymond and Captain John B. Turner, men to whom Chicago is greatly indebted, it reached Elgin, forty miles westward. So cheaply and honestly was it built, and from the time it was finished to Elgin, forty miles, so large and lucrative was its business, that it paid large dividends, and demonstrated that Illinois railways could be made profitable investments. It became, in fact, the parent of the vast railway system of the West. It was marvelous how rapidly railways were projected in all directions, and how quickly they were built.

The Michigan Southern Railway was the first great eastern line to reach this city, which it did on the 20th of February, 1852. The Michigan Central was opened May 20th of the same year. These gave a very great impulse to the growth and prosperity of the city. These were times when the coming of great enterprises seemed to fill the air, and the men were found who where ready to grasp and execute them. The necessity of binding the South and the North together by iron bands had been broached and talked of, in Congress and elsewhere in 1848 , and a few sagacious men had suggested the granting of alternate sections of the public lands to aid in the construction of the road as the only means by which it could be built. It had worked admirably in the case of the Illinois \& Michigan Canal, and it was agreed that the importance 


\section{Żilfiam $2 \mathfrak{B r a g i g}$}

of the work would justify a similar grant in aid of a great through line from the Lakes to the Gulf of Mexico. With the characteristic forecast and energy of her citizens, Chicago furnished the man who combined all interests and furnished the friends of the measure in Congress the means to carry it. That man was John S. Wright, who, as before stated, was one of the most far-seeing and valuable citizens Chicago ever had. The whirl and excitement in which he lived clouded his mind toward the close of his life; but if any one among our earlier citizens deserves a monument to his memory, that man is John S. Wright. I had the same office with him in I849, and hence know personally of what I speak. At his own expense he printed thousands of circulars, stating briefly, but with sufficient fullness, the arguments in favor of building the road, its effect upon the commerce and the social and political welfare of the Union; that in granting the lands the Government would lose nothing, as the alternate sections would at once command double the price of both. To this a petition to Congress to make the grant was attached. At that time such mail matter went free to postmasters, and with a small circular asking them to interest themselves in getting signers to the petitions, or to put them in the hands of those who would, Mr. Wright (giving employment to his clerk for weeks) sent two or three of them to 


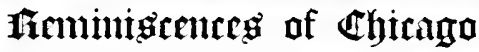

every postmaster between the Lakes and the Gulf of Mexico. In the early part of the session of I 849-50 these petitions began to pour into Congress by the thousands, and still all through the summer of I 849 they kept coming. Members from all sections stood aghast at this deluge of public opinion that seemed about to overwhelm them, unless they at once passed a law making a grant of lands to the states to open a railway from Chicago to the Gulf of Mexico. Our senators, Douglas and Shielcls, and representatives, Wentworth and others, saw their opportunity, and the bill was passed on the 2oth day of September, I 850 . On the Ioth of February, I $85 \mathrm{I}$, the Illinois Legislature chartered the company, and its construction was placed in the hands of Colonel R. B. Mason. I need not add that a better selection could not possibly have been made.

Permit me to say here, by way of parenthesis, that omnibuses and horse-cars were introduced nearly ten years after this time. The City Railway Company was chartered February I4, I 859. Pardon the remark, that whatever honor attaches to driving the first spike belongs to your speaker. It was done on State, corner of Randolph. The road reached Twelfth Street on the 25th of April, I 859, only seventeen years ago. Now the whole city is gridironed with them, and they are essential to its business life. 


\section{Zmilliam $2 \mathfrak{B r a g g}$}

I should like to give you the history of the Rock Island, the Alton \& St. Louis, the Burlington \& Quincy, the Pittsburgh \& Fort Wayne, and other roads, but time and space forbid. For several years succeeding I 854 the leading men of Chicago had to endure a great deal of eating and drinking, as our railways were opened to cities in all directions; and for this service, as for all others, they showed a capacity and willingness, as well as a modesty, which has made them distinguished all over the country. On the Ioth of May, I 869, the Central and Union Pacific railways joined rails at Promontory Point, thus completing the grand railway system across the continent. And here I may be permitted the incidental remark that we who live with them, and enjoy the first fruits of their enterprise, do not sufficiently honor the men who bridge our great rivers and bind every section of the Union together in bands of iron and steel, never to be broken,- such men as Wm. B. Ogden, John B. Turner, R. B. Mason, Thomas C. Durant, Leland Stanford, and scores of others that might be named. History shows that it was not only the men who bore the victorious eagles of old Rome through distant nations, but who built roads to connect them with the Eternal City, that received the highest honors. Thus it was that great national thoroughfares were built thousands of miles long, from the North to the Black Sea, and as in that case all roads 


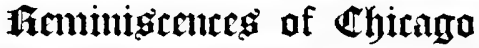

pointed towards Rome, so at least nine-tenths of all the roads in all this broad land point to Chicago. Do you know that the title even now worn by the Pope of Rome has come down to him from those old road-builders? Pontifex Maximus simply means the greatest bridge-builder, the proudest, and thus far the most enduring, title ever worn by earthly monarch. Let our city honor the men for making Chicago commercially in this centennial year what imperial Rome was politically in past ages. While we give all honor to these men, let not the name of John S. Wright be forgotten, who, addressing himself to even the greater work, in 1849 , combined and gave direction to the political and moral forces that enabled them to complete the grandest system of improvements ever made in the history of the world.

You will expect me to say something of the press of the city. In 1848 the Jourmal had rooms in what was then the Saloon Building, on the southeast corner of Clark and Lake streets. The Gom of the Prairie, and the Trilune, as its daily, maintained a precarious existence in an old wooden shanty on the northwest corner of Lake and Clark streets. Messrs. Wheeler, Stewart, and Scripps were the editors. It was burned out, and then located at No. 17 I $1 / 2$ Lake Street. My friend the Honorable John Wentworth published the Democrat in very aristocratic quarters - at 


\section{Żilliam $\mathfrak{B r a g i g}$}

Jackson Hall, on La Salle Street, just south of Lake. He had the only Hoe power press in the city. In the fall of 1849 , finding I preferred my old occupation of using books rather than of selling them, I disposed of my interest in the book-store to my partners. It was the original of the great house of Jansen, McClurg and Company. The leading member of the firm now - my brother-in-law-I left in the store a mere boy, whose duties were to sweep out, carry packages, and generally to do a boy's business. I mention this as an example for the boys who hear me to follow.

I then formed a partnership with $\mathrm{J}$. Ambrose Wight, then editor of the Prairie Farmer,a most valuable paper owned by John $S$. Wright, - and we bought out the Herald of the Prairies, a religous paper, the organ alike of the Presbyterians and Congregationalists of the Northwest. The latter half of the concern survives in the Adrance. It was then published on Wells Street, on the corner of the alley between Lake and Randolph streets. We soon moved to I 7 I Lake Street, next door to the Tritune; and in the rear building, on an old Adams press, the first power press ever brought to the city, we printed our own paper, and also the Tribune, for Messrs. Stewart, Wheeler \& Scripps. The press was driven by Emery's horsepower, on which traveled, hour by hour, an old black Canadian pony. So far as my interest in the splendid machinery 


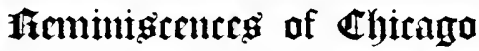

of the Tribune is concerned, that old blind pony ground out its beginnings, tramping on the revolving platform of Emery's horse-power.

By the autumn of $185 \mathrm{I}$ Mr. Wight, a man who, as editor of the Pratrie Farmer, did very much toward laying the foundations of the rapid progress and the great prosperity of the West, and now pastor of the Presbyterian Church at Bay City, Michigan, and myself, found out by sad experience that the Prairie Hirald, as we then called it, could not be made to support two families, for we had scarcely paid current expenses. I therefore sold out to Mr. Wight, taking in payment his homestead lots on Harrison Street. That winter rather than have nothing to clo I remained in his office with him, working for the large sum of one dollar per day. After a vacation of a few months, the late John L. Scripps and myself formed a partnership and issued the first number of the Dimocratic Press on the I6th of September, I852. We started on a borrowed capital of $\$ 6,000$, which all disappeared from sight in about six weeks. We put in all our services and profits, and about all the money we could borrow, never drawing a cent from the firm till after the first of January, I 855 . This required nerve and the using up of funds, to a very considerable amount, which we had obtained from the sale of real estate; but we thought we could see future profit in the business and we 


\section{Zmilliam 2rogig}

worked on, never heeding discouragements for a moment. The hard times of $1857-58$ brought the Democratic Press and the Tribune together, and Dr. Ray, J. Medill, John L. Scripps and myself became equal partners, with Mr. Cowles as business manager. Dr. Ray and Mr. Scripps have ceased from their labors, but not till they had done most effective and valuable work in the development and progress of Chicago. Mr. Scripps was postmaster during Mr. Lincoln's first administration. Both he and Dr. Ray were able and very cultivated gentlemen, and the memory of them should have a high place in the esteem and gratitude of their fellow-citizens. Mr. Medill, Mr. Cowles, and myself still stand by the old Tribune, with what efficiency and success the reading public can best judge.

I should like to have an hour to pay a passing tribute to the men who gave character to Chicago in 1848 and the years that followed. To Thomas Richmond, still with us; to John P. Chapin, Charles Walker and Captain Bristol, heavy dealers on Water Street; to Judge Giles Spring, Judge George Manierre, S. Lisle Smith, William H. Brown, George W. Meeker, Daniel McIlroy, James H. Collins, and others of the bench and bar; to Drs. Maxwell, Egan and Brainard; to Editors Dick Wilson, T. A. Stewart, John E. Wheeler, and James F. Ballantyne, as well as to Ray and Scripps; to the Rev. Dr. Tucker, Parson Barlow, and 


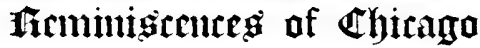

perhaps several others of the clergy. I should like to speak of Mayors F. C. Sherman, James Curtiss, J. H. Woodworth, and Thomas Dyer, all of whom have been relieved of earthly cares. Many of our oldest citizens still linger among us. Of these Colonel Gurdon S. Hubbard first came to Chicago in 1818 , the year Illinois became a state. Still hale and happy, may he long bless Chicago with his presence. Of our ex-mayors previous to 1860 , William B. Ogden, the first, Buckner S. Morris, B. W. Raymond, Walter S. Gurnee, Charles M. Gray, Isaac L. Miliken, Levi D. Boone, John Wentworth, and John C. Haines are still living. Of the clergy we still have the Rev. Dr. R. W. Patterson, "Whose praise," like one of old, " is in all the churches." Of our leading citizens we still have a host, almost too numerous to mention. The names of Jerome Beecher, General Webster, Timothy and Walter Wright, S. B. Cobb, Orrington Lunt, Philo Carpenter, Frederick and Nelson Tultle, Peter L. Yoe, C. N. Holden, Charles L. and John Wilson, E. H. Hadlock, E. D. Taylor, Judge J. D. Caton, J. Y. Scammon, Grant Goodrich, E. B. and Mancel Talcott, Mahlon D. Ogclen, E. H. Sheldon, Mat. Laflin, James H. Reese, C. H. McCormick and brothers, P. W. Gates, A. Pierce, T. B. Carter, General S. L. Brown, Peter Page, William Locke, Buckner S. Morris, Captain Bates, and many others, will at once recur to our older citizens. 


\section{Zillyiam $2 \mathfrak{B r o g g}$}

Some of these gentlemen were not quite so full of purse when they came here as now. Standing in the parlor of the Merchants' Savings, Loan and Trust Company, five or six years ago, talking with the president, Sol. A. Smith, E. H. Haddock, Dr. Foster, and perhaps two or three others, in came Mr. Cobb, smiling and rubbing his hands in the greatest glee. "Well, what makes you so happy?" said one. " OOh," said Cobb, " this is the first day of June, the anniversary of my arrival in Chicago in 1833." "Yes," said Haddock, "the first time I saw you, Cobb, you were bossing a lot of Hoosiers weatherboarding a shanty-tavern for Jim Kinzie." “Well," Cobb retorted, in the best of humor, "you needn't put on any airs, for the first time I saw you, you were shingling an outhouse." Jokes and early reminiscences were then in order. It transpired that our solid president of the South Side Horse Railway left Montpelier, Vermont, with forty dollars in his pocket, but by some mishap when he reached Buffalo he had only nine dollars left. This was exactly the fare on the schooner to Chicago, but the captain told him he might buy some provisions, and if he would make no trouble and sleep on deck the boy could come to Chicago for what was left. Cobb got some sheeting, which some lady fellow-passengers sewed up for him, and he filled it with shavings, and this made his bed on deck. He got a ham, had it boiled, 


\section{firmintatenteg of Elyitago}

bought some bread, and, thus equipped and provisioned, he set sail for Chicago. There was then no entrance to the Chicago River, and the vessel anchored outsicle, a long way out, and the cabin passengers went ashore with the captain in a Mackinaw boat. A storm springing up, the mate lay off for three days between Michigan City and Waukegan. When the vessel returned, a cabin passenger, who had returned for baggage, was surprised to find Cobb still aboard. Cobb told him that the captain had gone back on him, and would not let him go ashore without the other three dollars, and what to do he did not know. This gentleman lent him the three dollars, and $\mathrm{Cobb}$ gladly came ashore. Though he knew notining of the carpenter's trade, he accepted a situation to boss some Hoosiers, who were at work on Mr. Kinzie's excuse for a hotel, at $\$ 2.75$ per day, and soon paid his friend. From that time to this he has seldom borrowed any money. Mr. Haddock also came to Chicago, I think, as a small grocer, and now these gentlemen are numbered among our millionaires. Young men, the means by which they have achieved success are exceelingly simple. They have sternly avoided all mere speculation; they have attended closely to legitimate business and invested any accumulating surplus in real estate. Go ye and lo likewise, and your success will be equally sure.

Having seen Chicago in 1848 with no 


\section{Zilliam 25ragg}

railways, no pavements, no sewers, scarcely an apology for waterworks - a mere city of shanties built on the black prairie soil - the temptation to imagine for her a magnificent future is almost irresistible.

I beg leave with characteristic Chicago modesty to refer to a prophecy which I ventured to make in I854. I had just written and published the first exhaustive account of our railway system, followed by a history - the first also - of the city. In the closing paragraph I had the following sentences. The city had then not quite completed the seventeenth year of its existence, and I asked:

"What will the next seventeen years accomplish? We are now (1854) in direct railroad connection with all the Atlantic cities from Portland to Baltimore. Five, at most eight, years will extend the circle to New Orleans. By that time also we shall shake hands with the rich copper and iron mines of Lake Superior, both by canal and railroad, and long ere another seventeen years have passed away we shall have a great national railroad from Chicago to Puget Sound, with a branch to San Francisco.'

By the time the building of the road was fairly undertaken, San Francisco had grown so largely in wealth and population that the main line was forced to that city. But in June, I 869, two years before the thirty-four years in the life of the city had passed away, I rode from 


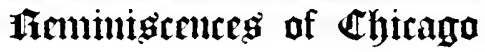

Chicago to Sacramento with my good friend George M. Pullman in one of his splendid palace cars, with a dining car attached, and no one could possibly fare better than we did on the entire trip. Another line was open from Sacramento to Vallejo, nearly right across the bay from the City of the Golden Gate, so that practically the prophecy was literally fulfilled. Perhaps it was only a fortunate guess, and as I was educated in New England, you will permit me to guess again, and to bound the city for you on the nation's second centennial; viz., on the $4^{\text {th }}$ of July, 1976. I think the north line will probably begin on the lake shore half-way between Evanston and Winnetka, and run due west to a point a least a mile west of the Aux Plaines River; thence due south to an east and west line that will include Blue Island, and thence southeast from Blue Island to the Indiana State line, and thence on that line to Lake Michigan. With my eye on the vast country tributary to the city, I estimate that Chicago will then contain at least $3,000,000$ of people, and I would sooner say 4,000,000 than any less than 3,000,000. I base my opinions on the fact that the gastronomic argument controls mankincl. Men will go and live where they can get the most and best food for the least labor. In this respect what city in the world can compete with Chicago? And I also assume that the nation for the next hundred years will remain one united, free and happy people. 


\section{Zmilliam $\mathfrak{D r a g i g}$}

But, gentlemen, in order to realize the magnificent destiny which Providence seems to have marked out for our city, permit me to say, in conclusion, that the moral and religious welfare of the city must be carefully guarded and promoted. Philo Carpenter (still among us) and Captain Johnson established the first Sunday school here July 30, I832, and the Rev. Jeremiah Porter (also still living) organized and became pastor of the First Presbyterian Church (now Dr. Mitchell's) on the 26th of June, 1833. Brave old Jesse Walker, the pioneer Methodist, also preached sound doctrine in the earliest years of the Town of Chicago. All other denominations were also on the ground early, and through all her former history our people seemed as active and earnest in religious efforts as they were enterprising and successful in mercantile and other businesses. Let all our churches address themselves earnestly, faithfully, to the work of moralizingif you please, converting - the people, working as their Divine Master would have them work; let respectable men, honest men, and especially religious men, go to the polls, and banish from places of trust and power those who are stealing their substance and corrupting, aye, even poisoning, the very life-blood of the city; let us all, my friends, do our whole duty as citizens and as men, ever acting upon the Divine maxims that "Righteousness exalteth a nation," that "Godliness is profitable for all 


\section{fremintsitcures of Ghiraga}

things," and with God's blessing Chicago, as in the past, so in the future, shall far outstrip in wealth, population, and power all the anticipations of her most enthusiastic and sanguine citizens. 


\section{Charleg $\mathbb{C l e a b e r}{ }^{1}$}

[Extracts from articles which appeared first in The Chicago Tribune.]

TO the south of the village was an almost interminable prairie, said to be three hundred miles in length, with only one small belt of timber to break the monotony of its level surface, reaching, as we were told, to the most southern point of the state, to which you could travel by crossing only that one small belt of timber, before mentioned, not a quarter of a mile in width. The country immediately around the village was very low and wet, the banks of the river not being more than three or four feet above the level of the water. More than one-third of the river was covered with wild rice, leaving but a small stream in the center.

Parties informed us that in the spring we should find it almost impossible to get around for the mud - truth very forcibly illustrated

${ }^{1} \mathrm{Mr}$. Cleaver came to Chicago in 1833 , and although we have in the main taken the portion of his reminiscences dealing with conditions in the forties and fifties, occasionally items of an earlier period occur. At the point where our selections begin, he had been leading up to the gradual emancipation of Chicago from the level of Lake Michigan.-ED. 


\section{fremintitenteg of ôytaga}

when a few months later I got into a wagon to go about a mile and a half northwest, to a house Daniel Elston was building on the west side of the river. It was with the greatest difficulty that two good horses could pull the empty wagon through the two feet of mud and water across the prairie we had to pass. I once heard Mr. Elston's place called "The Mud Farm,' not an inappropriate name for it at that time. A year or two later I saw many teams stuck fast in the streets of the village.

I remember, once, a stage-coach got mired on Clark Street, opposite the present Sherman House, where it remained several days, with a board driven in the mud at the side of it bearing this inscription: "No bottom here." I once saw a ladly stuck in the mud in the middle of Ranclolph Street at the crossing of La Salle. She was evidently in need of help, as every time she moved she sank deeper and deeper. An old gentleman from the country, seeing the situation, offered to help her, which had such an effect upon her modesty that with one desperate effort she drew her fect out minus her shoes, which were afterward found over a foot deep in the mire, and reached the sidewalk in her stockings. I could tell innumerable tales of the dreadfully muddy roads we had to encounter, but a few such will suffice.

In 1838 or 1839 the only way two of our most fashionable young ladies from the North Side could get to the Presbyterian Church on 


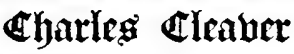

Clark Street near Lake was by riding in a dung-cart, with robes thrown on the bottom on which they sat. I once saw those same ladies clumped on the sidewalk in front of the church through the negligence of their driver in not putting in the bolt.

Another story, told in a lecture given by James A. Marshall, is rather more than I can vouch for. It was this: That our minister, who was then a young bachelor, in walking home with a young lady from Wednesday evening meeting, got into a slough, and in their endeavors to extricate themselves kept sinking deeper and deeper, until they were more than waist-deep in mud and water, and that it was only from their screaming for help that assistance came and saved them from a muddy and watery grave.

I know of no slough that was deep enough for that except one running south from the river about State Street, gradually lessening to about Adams Street. There was also a very wet spot, or slough, on Clark Street south of Washington. The village trustees, wishing to drain it and having no fund on hand, applied to Strachan \& Scott, the first brokers that came here, for a loan of $\$ 60$; but the wary Scotchmen refused to let them have it unless E. B. Williams endorsed it, which he did. This was probably the first loan made by the city of Chicago. Compare it with the millions she has borrowed since. What a contrast! 


\section{firministenteg of ethitaga}

Before leaving the subject, I must say a few words respecting the early efforts of our city fathers to effectually drain the village. As I have said before, Chicago was very low and exceedingly wet. The first effort made was on Lake Street, where, after mature deliberation, our village solons passed an ordinance for the digging out of the street to the depth of three feet-a little the deeper in the center. This naturally drained the lots contiguous to it, and on being covered with long, heavy planks, or timber, running from the sidewalk to the center of the roadway, for a few months after it was finished made a very good street; but it was soon found that heavy teams going over it worked the timbers into the mud, and it was consequently squash, squash, until at last, in wet weather, the mud would splash up into the horses' faces, and the plan was condemned as a failure. It was triecl two or three years, when the planks were removed, and it was filled up two or three feet above the original surface. This was found to work better, as it naturally would, and the same system of filling up has been continued from time to time, until some of the streets are five or six feet above the original surface of the prairie. The filling up answered a clouble purpose, as it not only made better roads, but it enabled the owners of the adjoining lots to have good cellars without groing much below the level of the prairie, thus getting a drainage into the river. 


\section{Uharleg Cleaber}

The first year or two we were here there was not a cellar in Chicago. A good joke was told about the first brick Tremont House that was put up. Of course it was at first built to the grade of that period; but as the grade was every now and then established higher and still higher, it at last left the hotel three or four feet below the surface of the road in front of it, and steps were built around it both on Lake and Dearborn streets for the convenience of persons going there or passing along the sidewalk.

A wag of a fellow from New Orleans, while visiting here, wrote back to his paper that they need not talk any more about the low land of New Orleans, for Chicago had got a brick hotel five stories high that was so heavy that it had sunk into the soft soil several feet, and had forced the ground up into the street around it. I must say it had that appearance. The building was afterward raised eight feet, bringing it up to the grade, and making cellars and basements underneath. It was the first brick building ever raised in Chicago, and the raising was done at a cost to the proprietors, Ira and James Couch, of some $\$ 45,000$. The contractor, I think, came from Boston, and many were the prophecies that the building would fail down during the process; but it was raised without the breaking of a pane of glass, although it was 160 by 180 feet. After the success attending the raising of the Tremont many others were raised to grade, and at last 


\section{fremintistentes of $\mathfrak{C h i t a g a}$}

one-half of a block of heavy buildings on Lake Street were successfully raised. It took 5,000 screws and 500 men to accomplish it.

The North Side between the river and North State Street was very wet,- - the water lay six to nine inches deep the year round,- - and on the West Sicle for ten miles out the water lay in places two feet deep, and in wet weather the whole surface was covered with water, with the exception of the two ridges between the city and the Des Plaines River. I built, in the fall of '36, on the corner of Washington and Jefferson streets, and many a time had to wade ankle-dleep in water to get there before I cut a ditch to the river to drain it.

On taking a trip to the Northwest in the spring of '35, the water was so deep a little north of Fullerton Avenue, on the Milwaukee road, that it came into the wagon-box several times before we reached the ridge at Jefferson. In going out to a convention, June I, I 849, there was so much water on the prairie west of the city that it took us nearly the whole day to reach Doty's Hotel, on the ridge about ten miles west of the courthouse. We were, of course, traveling in wagons, as that was long before the era of railroads. But I have said enough to show the character of the soil of Chicago and surrounding country. It certainly was decidedly a very low and wet spot on which to build a city before it was drained and sewered, and the only wonder is that it has become the 


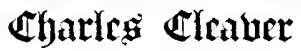

magnificent city that we boast of at the present day, with blocks of buildings far surpassing in elegance of structure, durability, and size any that can be found in the business parts of either London or Paris.

In I836 I drove up to Milwaukee, when the most of the village was on the west side, at Kilbourne Town, although they had made a beginning to build up the Cream City even at that early day. The Milwaukee House, a large frame hotel, was just opened, being built on one of the highest hills in the city. It has since been lowered about fifty feet, to bring it on a level with the rest of the town. From my first visit for twenty years I went there continually, marked its growth, and many a time listened to the boasts of its citizens that it was going to rival Chicago in its growth, and did actually contain as many inhabitants as the Garden City. The runners from the hotel would go on board the Eastern boats and tell passengers such tales of the dreadful sickness and daily deaths in Chicago that many a one was frightened and deterred from coming here.

I was with Captain Ward on the first steamer that ever entered the river, which was then filled with numerous mud banks, on which we grounded several times before getting up to where the wharves now are. The citizens were about crazy with delight at seeing the boat 


\section{fremintwernes of $\mathfrak{T h i t a g a ~}$}

enter, and got up quite an impromptu glorification. Waukegan was not then settled. Kenosha, or Southport, as it was called, was just laid out, and Root River, on which is located Racine, was crossed about three miles from its mouth. In I 842 or I 843 I first visited Galena, then quite a city of note, doing a larger wholesale business than Chicago. It was the center of the mining district for lead, and was the point at which all the shipments were made for the South and East, being the distributing point for the upper Mississippi and Northwest. From there Chicago received its first shipment of clarified sugar, bought from the agent of the St. Louis refinery, who was stationed there. It was only sixty barrels, but was the forerumner of an immense trade afterward clone with St. Louis, through an agent appointed here.

In the fall of 1842 I made two trips to St. Louis for the purchase of sugar and molasses, being the first ever brought into the city direct from the South. The route was from here to Peru by stage, and from there by boat. The water was very low-so much so that there were only two small boats running, out of about twenty in the trade. The rest were stuck on the different sandbars, some ten or twetve being at Beardstown. The small boat on which I took passage only drew about two feet of water. Consequently she continued her trips, but was a whole week reaching St. Louis. 


\section{Gharlegi oleaber}

The deck hands on board were all slaves, and the way the poor fellows were treated was really shameful. After meals in the cabin everything was swept off the plates into tin pans and then taken below, when the clarkies would scramble for the contents like so many hogs.

At Beardstown the boat grounded, and the darkies were driven into the water to float a hundred barrels of whisky over the bar. When thus lightened, they pried her over; and yet, with this wretched treatment, they were the jolliest, merriest set of fellows ever seen, singing and playing when they were not at work, as if they had not a trouble or care in the world. Just opposite Alton, at the entrance to the Mississippi, she struck a snag and nearly sank, but, after running ashore, they stuck their jackcoats into the hole and continued their journey as if nothing had happened, reaching the city a few hours afterward without further mishap. A second trip I made soon after took over two weeks on the river.

There is one other episode in my early travels which I must relate, particularly as it was made with others, and was, I think, the first political convention ever attended by Chicagoans. It was in the presidential canvass of I 840--the year Harrison was elected. Some seventy of us were nominated to attend a convention to be held at Springfield, and, as we wished to make a sensation, we determined 


\section{Ihominigtcutes of Ehitago}

to get the thing up in style. Great preparations were malle. We secured fourteen of the best teams in town, got new canvas covers made for the wagons, and bought four tents. We also borrowed the government yawl-the largest in the city-had it rigged up as a twomasted ship, set it on the strongest wagon we could find, and had it clrawn by six splendid gray horses. Thus equipped, with four sailors on board, a good band, and a six-pound cannon to fire occasional salutes, made quite an addition to our cavalcade of fourteen wagrons, we went off with flying colors, amid the cheers and well-wishes of the numerous friends that accompanied us a few miles out. Major-General, then Captain, Hunter, was our marshal, and the whole delegation was chosen from the best class of citizens, of whom but few, very few, remain: Gurdon S. Hubbard, Stephen F. Gale, Thomas B. Carter, Robert Freeman, and, Mr. Carter informs me, two of the musicians are still living, being all we could call to mind. It was June 7 , I think, that we started, leaving the city between nine and ten o'clock. From the Three-Mile House to the ridge, ten miles from town, took us about the whole day to accomplish. It was past five o'clock before we got our tents pitchel.

The prairie was covered with water, and the wagons would often sink up to the axles in muld, making it a most terlious and fatiguing journey. But on reaching the tavern, and 


\section{Eharleg $\mathbb{C l e a h e r}$}

finding an old coon there, with a barrel of hard cider, on the stoop-emblems of the Whig party - we soon made ourselves jovial around the camp-fire, over which some of our party were busy cooking supper, as it was understood, before starting, that none of the party were to go to taverns, but all fare alike, sleeping under the tents. We were, of course, well supplied with buffalo-robes and blankets. These, with a little hay under them, made comfortable beds. We set a watch in true military style, though it was hardly thought necessary so near to the city.

We were astir by sunrise the next morning, and, after partaking of breakfast, started again on our journey, reaching Joliet, where we again encamped for the night. During the evening we were visited by a few of the citizens, who advised us to put on a strong guard during the night, as a party of Irishmen at work on the canal had determined to burn our vessel. On receiving this information we took measures at once for its protection. The wagons were placed in a circle, the vessel in the center, and the horses corraled in the enclosure. Then we doubled the guard, which was relieved every two hours, and, thus prepared for any emergency, sought our tents. About twelve or one o'clock the guard arrested two men found sneaking under the wagons, and held them until morning. With that exception we passed a quiet night, but in the morning received decisive 


\section{firmintigenteg of thitago}

information that we should be attacked in fording the river.

When all preparations were macle for a start, our marshal rode along the line, telling those who had not already done so to load their arms, consisting of shot-guns and old horse-pistols (revolvers being then unknown), but to be sure and not fire until he gave the word of command. Fortunately we escaped without bloodshed, but it looked very serious for about half an hour. When we reached the ford we found a party of two hundred or three hundred men and boys assembled to dispute our passage. However, we continued our course, surrounded by a howling mob, and part of the time amid showers of stones thrown from the adjoining bluff, until we came to a spot where two stores were built-one on either side of the street-and there we came to a halt, as they had tied a rope from one building to the other, with a red petticoat dangling in the midst, used by the Democrats to show disrespect to General Harrison, whom they called the "Old-Woman Candidate." Seeing us brought to a stand, the mob redoubled their shouts and noise from their tin horns, kettles, etc. General Hunter, ricling to the front, took in the situation at a glance. It was either forward or fight. He chose the former, ancl gave the word of command, knowing it would be at the loss of our masts in the vessel. And sure enough, down came the fore-and-aft 


\section{OTharleg oleauer}

topmast with a crash, inciting the crowd to increased violence, noise, and tumult. One of the party got so excited that he snatched a tin horn from a boy and struck the marshal's horse. When he reached for his pistols, the fellow made a hasty retreat into his store. After proceeding a short distance, we came to the open prairie, and a halt was ordered for repairs. It took less than half an hour for our sailors to go aloft, splice the masts, and make all taut again. Then it became our turn to hurrah, which we did with a will, and were molested no further. But the delegation that were to join us from the village, being deterred from fear, were set upon by the mob and pelted out of town with rotten eggs. This was Democracy in ' 40 -we were Whigs. From that time forward we had no further trouble from our opponents. In fact, the farmers along our route treated us with the greatest hospitality and kindness. One in particular, I remember, met us with a number of hams, bread, etc., in his wagon, and when we arrived at his home said, "Now, boys, just help yourselves to anything you want; there is plenty of colll in the crib, potatoes in the cellar, and two or three fat sheep in the flock," which he had killed for us. In the morning he escorted us on our journey some miles, with twenty or thirty of his neighbors. In fact, with the exception before mentioned, we met with nothing but kindness the whole of our trip. 


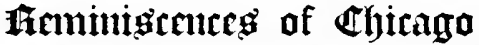

It took us about seven days to reach Springfield, where we met some 20,000 fellow-citizens from the central and southern portions of the state. There was one part of the procession that I shall never forget. It was a log-house, some twelve by sixteen feet, built on an immense truck, the wheels made of solid wood cut from a large tree. This was drawn by thirty yoke of oxen. A couple of coons were playing in the branches of a hickory tree at one corner of the house, and a barrel of hard cider stood by the door, with the latch-string hanging out. These were all emblems of the party in that year's canvass.

With the above exception, Chicago took the lead in everything. What with the vessel a wonder of wonders to the Southerners, who had never seen, or perhaps heard of, a sailingvessel before-the natty tents fixed up with buffalo-skin seats, interspersed with blue and red blankets, and festooned with the national flag and bunting, made such a display that the young ladies of the city paid us a deal of attention, making numerous visits, and cluring the early part of the evening complimented us with a serenade, which we returned later. One person, a Mr. Baker, threw open his house after miclnight, and entertained us in good style with cake and wine. We stayed two or three days, making many friends, and enjoyed ourselves greatly. But there was six or seven days' travel to reach home again, which was not so pleasant. 


\section{Oharles oleauer}

We were delayed by two public dinners on our route back - one given at Bloomington by a right jolly lady, who made a capital speech. We returned by way of Fox River, avoiding Joliet, traveling through Oswego, Aurora, and Naperville, and, though enjoying our three weeks' trip very much, we were glad to meet a large number of citizens to escort us again to our homes in Chicago. Such was a convention in old times. What a change forty years has brought about! By rail, the journey would take one night, a day or two spent in Springfield, and by night home again in luxurious sleeping-cars.

I have previously written several articles describing the difficulties the first settlers had in reaching Chicago, as well as their experiences in the first few years of residence here. I will now give you some idea of the trouble and difficulties they found in providing timber and material with which to build even the small houses and stores that were put up in those early days. There were no well-filled lumberyards, with an office adjoining, into which you could enter, as now, and leave your order for all the different kinds wanted. The whole stock of pine lumber in the village when I came here amounted to 5,000 or 6,000 feet of boards, and that was held at $\$ 60$ a thousand. Previous to 1833 most of the houses had been built of logs, some round, just as they came 


\section{fromintatenteg of $\mathfrak{c h i t a g a}$}

from the woods; while the more pretentious, belonging to the officers of the army and the great men of the village, were built of hewn logs. There was a small sawmill run by water about five or six miles up the North Branch, where they had built a dam across the stream, getting a three or four foot head of water; there was also a small steam sawmill, run by Captain Bemsley Huntoon, situated a little south of Division Street, at the mouth of a slough that emptied itself into the river at that point, in both of which they sawed out such timber as grew in the woods adjoining, consisting of oak, elm, poplar, white ash, etc. Of such lumber most of the houses were built, and any carpenter that has ever been compelled to use it, particularly in its green state, will appreciate its quality. In drying it will shrink, warp, and twist in every way, drawing out the nails, and, after a summer has passed, the siding will gape open, letting the wind through every joint. Such was the stuff used for building in 1833 and 1834. Some even did worse than that, and went into the woods for their scantling, cutting down small trees and squaring one side of them with the broadax. One of the largest houses built that winter, by Daniel Elston, was built with that very kind, both for uprights and rafters.

During the summer of 1834 the supply of pine lumber was greatly increased, and the price much lower. I think the most of it came 


\section{Eharleg Eleaber}

from Canada, but even as late as 1837 timber was so scarce (and heavy timber was used in large buildings in those times, the frame being pinned together by mortise and tennon) that, wanting considerable of it to put up a factory, I found it cheaper to purchase ten acres of land, ten or twelve miles up the North Branch, from which I cut the necessary logs, hauled them into the city on sleighs, and had them squared on the ground with the broadax. But heavy timber for frame buildings soon after that came into disuse, as it was found the present way of putting up frame buildings was much stronger and better. It used then to be called balloon framing. G. W. Snow, an old settler, had the credit of first originating the idea.

Lumber in 1837 had got to be more plentiful at $\$ \mathrm{I} 8$ to $\$ 20$ a thousand. I put up a building, 30 by 40 feet, two-story and basement, on the corner of Washington and Jefferson streets. It was the largest building on the West Side south of Lake Street, and, standing there alone for years, served as a beacon for many a belated traveler over the ten miles of prairie between the village and the Des Plaines River. At that time it seemed a long way out of town. There was but one shanty between it and Lake Street Bridge, and it really seemed quite a walk over the prairie to reach it.

The West Side at that time contained but few inhabitants. When a year or two later 


\section{fremintatenteg of $\mathbb{e r h i t a g a}$}

the village took upon itself city airs, the Third Ward, extending from the center of Lake Street south, and all west of the river, contained but sixty voters, the majority of whom were Whigs. It was a Whig ward, but that did not prevent the Democrats of that early day from colonizing about fifteen Irishmen from the North Side to try and carry it. I merely mention this fact as showing that the Democrat of 1839 was very much like his brother Democrat of I 880 . I might tell a good joke of two prominent politicians of that time-how they cursed and swore at us when they found we positively refused to receive their Irish votes, after they had furnished them for ten days with whisky and board; but as they are still living in the city, I will not mention names.

From I 838 to I 843 people began gradually to build a house here and there on the streets adjoining, between the location I had selected and the river; but the progress made was very slow. We were right in the midst of the panic which commenced in 1837 . I changed my location in I843, and built on Canal Street, just south of Madison, and still had an unobstructed view of the bridge at Lake Street, and walked to it over the greensward of the prairie. At this point it was foolishly supposed by many to be a good location for a residence, as it was a dry, good soil on the bank of the river, which was then a clear, running stream, and really looked pleasant. I built a brick house, 


\section{Uharteg ofleaber}

surrounded it with a garden, and had fine, growing fruit-trees; so, also, did two or three others, among whom were Charles Taylor and George Davis, whose widows are still living on the West Side; but before we reaped the fruits of it, business drew near us. Gates \& Co. started a foundry within a block of us, and in I 848 a lumber-yard was established on the adjoining lot. That settled our idea as to residence property, and in $1852 \mathrm{I}$ moved to the corner of Thirteenth Street and Michigan Avenue. Here I rented a house and garden that was nearly surrounded with prairie. But business again followed us, and six months after we settled there the Michigan Central Railroad put up a temporary depot directly opposite on the east side of the street. To be sure we had the pleasure of seeing the ironhorse make its daily trips to the city of our choice, but that hardly compensated us for the annoyance we continually received from the tramps and others that came on the cars begging for food and water; so we determined once more to pull up stakes, and selected a place on the lake shore two miles south of the city, in the grove, where Fortieth Street now is. But before speaking of that I will give you some idea of the expansion of the city in a southerly direction of what is called the South Side.

I think it was in 1836 or 1837 that the old Tremont was put up on the northwest corner 


\section{fremintwenteg of $\mathbb{C h i t a g o}$}

of Lake and Dearborn streets, owned and kept by Ira and James Couch, though in a very different style to what it has been kept the last twenty-five years. It was then a common country tavern, for the accommodation of farmers and others visiting the city. I have many a time met one of the proprietors on the prairie bringing a load of wood from the Dutchman's Point, twelve miles up the North Branch, and once or twice, when business was slack, met him on the road to Milwaukee, with a sleigh-load of butter, dried apples, etc., to trade off to the denizens of the Cream City and turn an honest dollar. In I838 the city had got as far south as Madison Street. Two of my friends built on the south sicle of Madison, directly facing Dearborn Street. This was the very outskirts of the city and seemed a long way from the center of businessClark and South Water streets. But it kept creeping southward, until in $\mathrm{I} 850$ it had reached Twelfth Street, where, on the northwest corner of that and State Street, stood the Southern Hotel. In I849 I was offered the ten acres adjoining, running from Twelfth to Fourteenth Street and west of State, for \$1,200. Mathew Latlin tells me he purchased it for $\$ I, 000$. It is part of the property that has lately been sold to the railroad for a depot at $\$ 200$ to $\$ 300$ a foot.

In I85 I I was offered, by the Marine Bank, twenty acres, running from State Strect to the 


\section{Uharleg $\mathbb{C l e a b e r}$}

lake, for $\$ 500$ an acre. A year or two later I was one of a committee to locate Dearborn Seminary. I urged them to locate between Wabash and Michigan avenues, just south of Fifteenth Street, which was offered us for $\$ 25$ a foot, both fronts; but it was rejected with scorn, inquiring of me where I expected to get the young ladies to fill the school in that neighborhood. At this time there was only a single buggy track running in a direct line across the prairie from the corner of State and Twelfth streets to the "oak woods," as the groves south of Thirty-first Street were then called. In driving to that point we only passed two houses-Mr. Clark's on Michigan Avenue and Sixteenth Street, who owned a farm there, and Myrick's Tavern at Twentyninth Street, who owned sixty or seventy acres from Twenty-seventh or Twenty-eighth to Thirty-first Street. Then we came to the Graves' tract of sixty or seventy acres, situated near the lake in the beautiful grove between Thirty-first and Thirty-third streets, on which was a house of resort called "The Cottage." The adjoining property of the same description, south of Thirty-third and north of Thirty-fifth streets, was, in I 852 , purchased by Senator Douglas, who donated ten acres of it to the Chicago University. This tract of seventy acres was owned before Douglas bought it by some bank in Philadelphia, and was offered for $\$ 7,000$. I urged its purchase by the city 


\section{fitministentes of Ehitago}

for a park through the papers of that day, but had my communications returned to me, with the remark that it certainly would benefit Cleaverville, but they clid not think it would benefit the citizens of Chicago, being so far out. From Thirty-fifth to Thirty-ninth Street was the Ellis farm of 200 acres, owned by Samuel Ellis, who lived in a clapboard house on the southwest corner of Thirty-fifth Street and Lake Avenue, where they had kept tavern for years, it being formerly the first station out of Chicago for the Detroit line of stages. It was about half a mile from "The Cottage" and three-quarters from Myrick's. These were then the only houses south of Thirteenth Street, except one or two small places on the river; but it was upon the Ellis farm that I determined to build a factory, and for that purpose purchased twenty acres of lim, on the lake shore, from the center of Lake Avenue to the lake, between Thirtyseventh and Thirty-ninth streets. It was thought to be a wild scheme, and many a time I was laughed at, and asked with a smile if I ever expected Chicago to reach as far south as that, being then two miles beyond the city limits, which were at Twenty-second Street. However, that did not deter me, even when I got out plans for a three-story building and cellar, 80 by 160 feet, and was informed that it would take 100 cords of stone and 400,000 brick to complete it. But it clid become a 


\section{Uharłeg oleauer}

matter of grave importance how I was to get the brick, stone, lumber, etc., on the ground, as the brick-kilns were on the West Side, near Twentieth Street, and there was no bridge south of Madison Street. But being accustomed to face difficulties, and, after looking the matter over, concluded the cheapest way was to build a scow and run a ferry over the river about Twenty-second Street, which I did for three or four months. But the trouble was not then over. Before the teamsters had been hauling thirty days the road track in some places got so deep in sand that they informed me that they should have to throw up the contract (which I think was only $\$$ I a thousand) unless I would build some half mile of plank road, which I accordingly had to clo, and also build a bridge in front of the university over a slough I 50 feet in length. The stone I had but little difficulty with, as I contracted to have that taken down by tug on canal-boats. But for the heavy oak timbers and joists which were needed I built another smaller scow and towed it down the lake shore with horses. This was before the Illinois Central Railroad had put any piling or crib-work in the lake, when the shore was a beautiful sandy beach, extending many feet from the high land to the water. I had, previously to this, put up several houses on the west side of the river, on the North Branch, near Division Street, for the use of my workmen, and wanted those moved to the lake 


\section{freministenteg of $\mathfrak{c h i t a g o ~}$}

shore at Thirty-eighth Street. The problem to be solved was how to get them there. Many difficulties were in the way of taking them by water; yet that seemed the only feasible plan. One great objection was that Chicago Avenue Briclge had no draw in it to let a boat pass; but, after taking advice upon the subject, I notified the city authorities they must remove it, as they had no right or authority to obstruct a navigable stream. They removed it after a day or two's delay. But that delay cost me the loss of one of the boats employed in moving the houses. I hired two canal-boats, lashed them abreast of each other, and chained two houses crossways on them. In this way we found no difficulty in going to the mouth of the river. But a storm had come up on the lake, which compelled us to wait three days until it subsided. A man who had been left on board as watchman, getting tired of such a solitary life, of his own accord hailed a passing tug, and by himself braved the rolling waves of Lake Michigan; and, though the storm had in a great measure abated, yet there was a heavy swell washing shoreward, and the consequence was, the minute the tug cast them off a couple of hunclred feet from land they began to drift in broarlside to the shore, and were soon driven up on the beach, the outer boat sinking, leaving the houses, to all appearances, pitching into the lake. But, fortunately, the chains held them, and, without further damage, 


\section{Uharleg Oleatuer}

they were landed on the shore. But we were not so fortunate with the boat, which was wrecked the following day before we could get a tug to lay hold of it. Two other trips were made, and four more houses safely landed without further loss.

Those houses are still standing, just north of Pier or Thirty-eighth Street, on Lake Avenue, and are the same that were floated down in $185 \mathrm{I}$, more than thirty years ago, and, with the brick building and slaughter-house erected the same year, were the commencement of the large settlement in that neighborhood. The following year I built several more cottages, and soon found it almost a necessity to build a meeting-house, which I did in 1854 , in which school was kept and the Gospel was preached for many years. This building was afterward removed to Hyde Park, and I think is now used as the Village-Hall. In 1857 one hundred acres were platted and laid out as the Village of Cleaverville - so named by the reporter for one of the papers of that dayand has since kept its cognomen, legally, at all events, although from the station on the Illinois Central Railroad being called Oakland, it has gradually been known by that name, until many suppose that to be the legal appellation, and want their title-papers so designated.

It was but a year after I erected the factory on the lake shore that the Michigan Central came thundering along with their rails and 


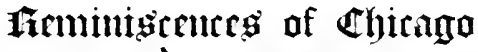

iron horse, within roo feet of the building, thus renclering it almost useless for the purpose for which part of it was erected-viz., a slaughterhouse for the city butchers to kill in. They began killing there, but the cars frightened the cattle so they dropped off one after the other, although Colonel Hancock made his début in it as a Chicago packer, killing a few hundred head of cattle that Winter. But others as well as myself soon recognized the locality as one of the most beautiful around Chicago for residence purposes, and I soon had an offer for a lot to build on, by Mr. Farrington, the wellknown wholesale grocer, who was the first, except myself, to erect a building on the village tract. Others soon followed, and, on the Illinois Central putting on a train to run three times a day, citizens began to be attracted by the beauty of the location, and the first week of their rumning I sold five or six lots. In I 853 I built a house for myself, where I have since resided, and still live to see the gradual but wonderful change that has taken place in the country around; from a farm, fenced in with a rail fence, to a populous neighborhood, filled up with elegant stone, brick, and frame houses, acknowledged by all to be one of the most beautiful suburbs of the eity, with its large brick school-houses, containing hundreds of children each, churches of all denominations, and improvements of every kind.

For the first ten or twelve years of my 


\section{Uharleg Oleaber}

residence there I had to depend on myself for everything that was done to improve the neighborhood. There were no Hyde Park officials, and the city would have nothing to do with us, so far as making streets and sewers were concerned. I well remember the making of Thirty-ninth Street. It was such a swamp, west of Cottage Grove Avenue, that I had to employ men to shovel it up, as a team could not work it. In fact, all the swales between the ridges were covered with water the summer through, breeding mosquitoes by the million, which was supposed to be one of the greatest draw backs to the settlement of the neighborhood. But with the drainage of the land they soon decreased, and on running a sewer from the lake in 1867 , west on the street mentioned to Langley Avenue, thus draining all the lots contiguous to it, they disappeared altogether.

When this part of the country was first settled there were no public conveyances of any kind. For years I drove in and out of the city in a buggy. Then came the first omnibus, running to Twelfth Street every hour. It was, after a year or two, extended to the city limits at Twenty-Second Street, and gradually more 'busses were put on. Then some public-spirited individual put on a four-horse omnibus, to run to Myrick's Tavern, on Thirtieth Street That continued until about 1855 or 1856 , when, I think, the horse-cars began to run, first to Twelfth, then to Twenty-second, extending 


\section{Ifemintitented of ohteago}

soon to Thirty-first, where they stopped for several years, until I 867 , when the track was laid to Thirty-ninth, its present terminus. All who ride on them now know what success they have met with, as they are continually filled to overflowing, though running every three or four minutes for sixteen hours out of the twenty-four. Could Doctor Egan and Senator Douglas arise from their graves, they would indeed look on with astonishment. I mention them, as the doctor was the first to get a charter through the legislature for a horse-railroad from the Calumet River to Chicago. He, the senator, and myself organized a company to build the road some time before it was commenced, but were defeated in the city council by their refusing us the right to lay down tracks in the city. Some two or three years after, the privilege was granted to others.

While writing of public improvements, I will mention the water-supply. Citizens, the first year or two of my residence here, went to the river-bank and clipperl it up by the pailful. Then for a few years it was carted from the lake shore, in water-carts, and sold at ten cents a barrel. After that, if I remember right, a stream was pumped from the shore into a tank or reservoir adjoining the steam flouring-mill built on the northeast corner of Lake Strcet and Michigan Avenue, run, if I remember right, by the late James $\mathrm{H}$. Wood- 


\section{Charleg $\mathbb{E l e a b r r}$}

worth. The two tanks were certainly not over twelve feet deep, and stood probably four feet above the level of the ground, and from this water was distributed through log pipes to a small portion of the city. This continued until about I855-56, when J. H. Dunham called a meeting of the citizens to meet over his store on South Water Street, to take into consideration the need of a better and purer supply of water. At that meeting there were only five individuals present, but it was the first of a series that at last accomplished the object sought, and was the commencement of the present system of supply throughout the city. For many years it was pumped from the shore at the present site of the waterworks, but finding at length that they pumped about as much small fish as they did water, the tunneling of the lake to the crib, two miles from shore, was conceived and successfully accomplished.

Seeing in your valuable paper the late statistics published by you of the business done in this city, for the past year, both in Packing and in Grain, I thought it would be interesting to those connected with the trade to know from what small proportions it originally sprang. I will commence with the butchering and packing business, and to do that must go back to the early days of 1833 , when Archibald Clybourn had a small log slaughter-house on the east 


\section{Themintigtenteg of ehitago}

side of the North Branch, a little south of the briclge now known by his name. He then killed weekly a few head of cattle, supplying the garrison, and also the townspeople, and was one of the first who afterward put up both beef and pork for the surrounding country and villages, north and west of us. He did quite an extensive trade as early as $1836-37$, and was reputed to be a wealthy man in those days, not only from success in his business, but also from his land speculations.

It was about that time, or probably a year or two later, that he made his famous trip to Milwaukee on horseback. He rode an old favorite gray horse of his, making the trip in ten or twelve hours, to secure a certain eighty acres of land, in or near the city, by which transaction he made some $\$ 20,000,-$ considered a large amount in those times,-and ever after gave his faithful old horse free fodcler in his barns and pastures. In the winter of $1842-43$, he slaughtered and packed for William Felt \& Co. two or three thousand head of cattle, to ship to New York Citythe first beef ever packed in this city for an Eastern market. The same season Gurclon S. Hubbard packed some cattle for the East, and perhaps he is entitled to the first place in Chicago packing, as he had a drove of about three hundred hogs brought in and sold to the villagers as early as $\mathrm{I} 833$, and from that time for many years was largely iclentified with the 


\section{Uharteg Uleawer}

packing interests of the city, continuing in the business as late as 1855 or ' 56 , perhaps later. Mark Noble also killed a beast now and then, and sold among the people in the early days of I833-34, keeping it up for two or three years later - when he married and left for Texas, making several trips to the city years after with large droves of cattle. His brother, John Noble, still resides on the north side of the city.

Sylvester Marsh also started a butcher-shop on Dearborn Street, between Lake and South Water streets, as early as 1834 , carrying it on until 1836 or 1837 , when, from his success in the business and land speculations, he thought he was rich enough and left for Dunkirk, N. Y., where in some unaccountable way he soon lost all he had, and in two or three years was back in Chicago, in partnership with George W. Dole, under the firm name of Dole \& Marsh. They did quite an extensive business, both in killing for market and also in packing for themselves and others, at their slaughter-house on the South Branch.

It was with this firm that Oramel S. and $R$. M. Hough served their apprenticeship to the packing business, who, for many years after, were extensively known among those connected with the packing interests of Chicago as Hough $\&$ Co., and Hough, Brown \& Co. Sherman (Orin) \& Pitkin (Nathaniel), an extensive drygoods firm of $1842-43$, also went heavily into 


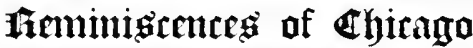

hog-packing that winter, keeping it up for several seasons thereafter; they went into it when pork was at the lowest price ever known in Chicago. I bought several loads of dressed hogs out of farmers' wagons that winter as low as \$I.25 a hundred. Packing in those early days was quite an experiment, and few were found willing to risk their money in it, as they had to carry everything packed till spring and then ship East by vessel. William and Norman Felt, extensive farmers near Rochester, N. Y., were the first to make a regular business of it, as they continued killing at different packinghouses in the city until about 1858 or 1859 , and after that for years were the most extensive shippers of live stock from this place. Moshier \& Clapp (Wm. B.) also packed largely of pork for the Eastern market as early as I 844 or I 845 ; they packed for a time in a store of Col. Gurdon $\mathrm{S}$. Hubbard, in the centre of the city, used by him for that purpose. They kept in the business for several years, until the death of $\mathrm{Mr}$. Clapp, about I850.

In connection with the slaughtering business of the city, I must not forget Absalom Funk, later Funk \& Albee, who for years kept the largest and best meat-market in the city. Mr. Funk had also several large farms near Bloomington, Ill., where he raised and fattened cattle for his own killing, making semi-monthly trips between the two places on horseback, following his droves of cattle. When railroads com- 


\section{Charleg $\mathbb{C l e n}$ wer}

menced bringing cattle to the city, rendering his riding unnecessary, he soon felt the want of his customary exercise, sickened and died, his partner, Cyrus P. Albee, following him some years later. Reynolds (Eri) \& Hayward (John) were also early packers of Chicago, taking Dole \& Marsh's packing-house, on the South Branch, where they carried on the business quite extensively for many years, packing for themselves and others.

Tobey (Orville H.) \& Booth (Heman D.) commenced business in their present location on the corner of 18 th and Grove streets, quite early. Mr. Tobey commenced first melting in a small rendering concern he bought of Sylvester Marsh, and moved there from the North Side, and from that worked themselves up to be the most noted shippers of pork to the old country, still keeping up their reputation to this day for curing the best meats.

Col. John L. Hancock came to the city about I 853 , making his first venture in packing by killing some 1,500 head of cattle in my slaughterhouse, on the lake shore at Thirty-eighth Street, but soon became one of the largest packers in the state, carrying on an extensive business at Bridgeport, both in beef and pork, for many years; and I believe is still there at his old trade. I have mentioned all of the first packers of Chicago; at all events, all I remember.

I think there were only about 35 ,000 head of cattle slaughtered during the season from 


\section{finmintüruted of ohitago}

October to January as late as 1857 , and perhaps about I 50,000 hogs; $*$ this seems a small business when compared with these times, when hogs are counted by the million, but it was then thought to be a very large trade. Up to this time, I 857 , I had taken all, or nearly all, the tallow and lard from the various packing-houses of the city, rendering it in the melting-house adjoining my factory, on the lake shore at Thirtyeighth Street, where I used to manufacture it into soap, candles, lard oil, neat's-foot oil, etc., supplying the country west and north of us, and also in the later years shipping tallow and oil to New York and Montreal.

I commenced in the fall of I834, when a few hundred pounds a week was all I could get from the different butchers; it kept increasing slowly until I 843 , when Felt and G. S. Hubbard commenced shipping beef, and Sherman \& Pitkin pork, when, finding it coning in faster than I could melt it by the old process by fire, I conceived the iclea of renclering by steam. John Rogers had tried it a year before in a small way, but dicl not make a success of it; but I found no trouble in bringing it into practical use, and from that clay to this it has been used for all melting purposes; and at this late day has been brought to such perfection, in

* Beer Packing.-Capital invested, $\$ 650,500$; number of cattle slaughtered, 2800; barrels packed, 97,500. Annual receipts, $\$ 824,000$. - Chicasol Diretery', December, 1850 . 


\section{OHarleg oleauer}

the close tanks made of boiler-iron, putting on steam at eighty to one hundred pounds to the inch, that a tank of lard or tallow can be melted in a few hours. The first tanks I used were of wood, and took twenty hours to render out. P. W. Gates \& Co., who had just then started as boiler-makers and machinists, set up the first boiler for me, with all the necessary coils, pipes, etc., and, from that time until $1856-57$, I did the melting, or nearly all of it, for all the packers then in the city.

A firm from Cincinnati, Johnson \& Co., put up extensive melting-works on the lake shore, north of Thirty-first Street, where they purchased five acres of Willard F. Myrick, in I 853 , and spent some $\$ 40,000$ in setting up their iron tanks, etc., but had not capital enough to carry it on, and it became a dead failure; but after it had stood idle for many years, Johnson came on and commenced suit against the Illinois Central Railroad Co. for ruining their business by putting their tracks between the building and the lake, and managed to get a check out of the company for $\$ 50,000$ damages. Gurdon S. Hubbard did his melting there for two or three years. Hough \& Co. were the next to put tanks and boilers into their packing-house at Briclgeport, about the year 1854-55; others soon followed; and in 1857 I gave up the business, and from that time all the different packing-houses have had their own tanks and melting apparatus, and there I 


\section{İeminigenteg of Ghitaga}

leave all reminiscences of early packers and packing.

I will now give my reaclers some idea of the beginnings of the present grain trade of the city of Chicago which has now reached such enormous proportions that it is counted by the millions of bushels; in speaking of its growth it will be well to divide it into four different eras, which will also mark the prosperity and growth of the city.

For the first three or four years, or until about I837, we were indebted to other states for the larger part of what was consumed in the village and surrounding country; that would comprise the first era. From that time to $\mathrm{I} 842$ or I 843 farmers began to raise enough produce for themselves and their neighbors' consumption, as well as supplying the citizens of Chicago with all that was necessary; but those years began to show the necessity of having some foreign market to take off their surplus produce, for in the winter of I842-43 farmers' produce of all kinds was so low it was hardly worth raising; for instance, dressed hogs sold as low as ten to twelve shillings a hundred, lard three dollars and a half a hundred, tallow six and a quarter, flour three clollars a barrel, oats and potatoes ten cents a bushel, eggs four to five cents a dozen, dressed chickens and prairie hens five cents each. Such a state of things could not last, as farmers found it impossible to raise it for the money, and graclu- 


\section{Uharles $\mathbb{C l e a b e r}$}

ally all classes of produce were held till spring, for shipment round the lakes by vessel to New York; this would end the second era.

From that period prices gradually improved; but the hauling of it so many miles took off nearly all the profit. Farmers living on Rock River would take five days to market thirty bushels of wheat, finding when they got home not over ten or twelve dollars left out of the price of their load; but for some purposes they had to have a little cash, and so continued to bring it. This lasted until 1850 or I $85 \mathrm{I}$. Previous to that time I have seen fifty teams in a line crossing the prairie west of us with their loads of grain for Chicago.

There was also another class of farmers from the south that used, in a measure, to supply the city with necessaries in the shape of green and dried apples, butter, hams, bacon, feathers, etc. These men would bring their loads two or three hundred miles, camping out on the way, cooking their rasher of bacon and corn-dodgers, and boiling their pot of coffee over the camp-fire, sleeping in their wagons at night and saving money enough out of their load to purchase a few bags of coffee, and the balance in salt - this was the invariable returnload of all Hoosiers, who used to come in great numbers in their curious-shaped covered wagons, known in old times as prairie-schooners. I have seen numbers of their teams camped out on the dry ground east of State Street. I once 


\section{fremintätented of $\mathbb{C h i t a g a}$}

counted one hundred and sixty from the roof of Bristol \& Porter's warehouse, on the corner of State and South Water streets; this closes the third era, about I 852, when the iron horse made its triumphant entry into the city from the East, snorting forth its volume of steam and smoke, a blessed day indeed for the Great West, for without the railroad what could we have done?

Before the Michigan Southern and the Michigan Central railroads entered Chicago from the East, the Galena \& Chicago Union Railroad Company was laying its tracks and pushing on to the West, making its first stopping-place at the Des Plaines River, then at Wheaton, then the Junction, then on to Elgin, Pigeon Prairie, Belvidere, Rockford, and other stations, until at last it reached Freeport, relieving the farmers at every stopping-place from their long and tedious journeys by tean, and enabling them to utilize their own labor and the service of their teams in improving their farms, and adding every season to the amount of grain sown, until with the great increase in the last few years of farm-machinery, and the facilities for moving and storing grain, there seems to be no end to the amount forwarded; and although railroads have stretched their iron arms through every county in the state, and thousands of miles into other states and territories west of us, it is as much and more than they can do to relieve the farmer of his surplus produce. What will be done with it in the next fifty years time alone will reveal. 


\section{Joseph Jefferson, Chícagoan}

[Reprinted from "The Autobiography of Joseph Jefferson," by permission of The Century Co.]

T $\mathrm{N}$ the year 1838 the new town of Chicago had just turned from an Indian village into a thriving little place, and my uncle had written to my father urging him to join in the management of the new theater which was then being built there. As each fresh venture presented itself, my father's hopeful nature predicted immediate and successful results. $\mathrm{He}$ had scarcely finished the letter when he declared that our fortunes were made, so we turned our faces towards the setting sun. In those days a journey from Albany to Chicago was no small undertaking for a large family in straitened circumstances; certain cherished articles had to be parted with to procure necessary comforts for the trip. I really do not know how, but we got from Albany to Schenectady, where we acted for a few nights with a company that was playing there. Several of the actors, who had received no salary for some time, decided to accompany my father and seek their fortunes in the West. As I remember it, our journey was long, but not tedious. We traveled part of the way in a fast-sailing packet-boat on the Erie Canal, 


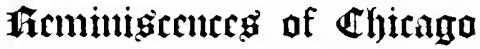

the only smoke issuing from the caboose stovepipe. I can remember our party admiring this craft with the same enthusiasm that we now express in looking at a fine ocean steamer. She was painted white and green and enlivened with blue window blinds and a broad red stripe running from bow to stern. Her name was the Pioneer, which was to us most suggestive, as our little band was among the early dramatic emigrants to the far West. The boat resembled a Noah's ark with a flat roof, and my father, like the patriarch of old, took his entire family on board, - with this clifference, however: he was required to pay his passage, it being understood between him and the captain that he should stop a night in Utica and one in Syracuse, give a theatrical entertainment in each place, and hand over the receipts in payment of our fare.

We acted in Utica for one night, and the receipts were quite gool. My father and mother were in high spirits, and there is no doubt that the captain had hopes that the next night's entertainment in Syracuse would liquidate our liabilities, for there was a visible improyement in the coffee at breakfast, and an extra piece of pie all around for dinner. The next night, unfortunately, the elements were against us; it rained in torrents and the attenclance was light, so that we were short of our passage money about ten clollars.

The captain, being a strict member of the 78 


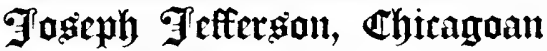

Church, could not attend either of the performances, and as he was in his heart most anxious to see what acting was like, he proposed that if the company would "cut up" for him and give him a private show in the cabin he would call it "square." Our actors, being highly legitimate, declined; but my mother, ever anxious to show off the histrionic qualities of her son, proposed that I should sing some comic songs for the captain, and so ransom the rest of the actors. The captain turned it over in his mind, - being, I am afraid, a little suspicious of my genius, - - but after due consideration consented. So he prepared himself for the entertainment, the cook and my mother comprising the rest of the audience. The actors had wisely retired to the upper deck, as they had been afflicted on former occasions. I now began a dismal comic song called "The Devil and Little Mike." It consisted of some twenty-five stanzas, each one containing two lines with a large margin of "whack fol de riddle." It was never clear whether the captain enjoyed this entertainment or not. My mother said he did, for, though the religious turn of his mind would naturally suppress any impulse to applaud, he said even before I had half finished that he was quite satisfied.

On our arrival in Buffalo we found another pioneer company, under the management of Dean and McKenney. Here we stayed over two or three days, waiting for the steamer to 


\section{Iremiutitentes of erhitatgo}

take us up the lakes. Marble was starring there; he was one of the first and best of the Yankee comedians. In those clays the stage New Englander was acted and dressed in a most extravagant manner. I remember seeing Marble play, and his costume was much after the present caricature of Uncle Sam, minus the stars but glorying in the stripes.

In a few days we steamed up the beautiful lakes of Erie, Huron and Michigan. The boat would stop sometimes for hours at one of the stations to take in wood, or a stray passenger, and then the Indians would paddle out to us in their canoes, offering their beadwork and moccasins for sale. Sometimes we would go ashore and walk on the beach, gathering pebbles, carnelians, and agates. I thought them of immense value, and kept my treasures for years afterwards. What a lovely trip it was as I remember it! Lake Huron at sunset is before me now-a purple sky melting into a golden horizon; rich green foliage on the banks; yellow sand with many-colored pebbles making the beach of the lake; the clear and glassy water; groups of Indians lolling on the banks, smoking their pipes and making baskets; the hills dotted with their little villages of tents made of skins and painted canvas; blue smoke curling slowly up in the calm summer air; and all the bright colors reflected in the lake. I stood there as a boy, skimming flat stones over the surface of the water, and now 


\section{Ioweph Tefferanon, Ghitagoan}

as I write in the autumn of my life these once quiet shores are covered with busy cities; the furnaces glow with melted iron, the locomotive screams and whistles along the road where once the ox-teams used to carry the mail, and corner lots and real-estate agents "fill the air." When we think that all these wonderful changes have taken place within the last fifty years, it is startling to speculate upon what the next half-century may bring about.

So day by day passes, till one night a light is espied in the distance, then another, and then many more dance and reflect themselves in the water. It is too late to go ashore, so we drop anchor. At sunrise we are all on deck looking at the haven of our destination, and there in the morning light, on the shores of Lake Michigan, stands the little town of Chicago, containing two thousand inhabitants. Aunt, uncle, and their children come to meet and welcome us. Then there is such a shaking of hands and a kiss all around, and "Why, how well you are looking!' and "Is that Charlie? How he has grown!" "Why, that's not Joe! Dear me, who'd have believed it?"' And then we all laugh again and have another kiss.

The captain said he had enjoyed a splendid trip-such fun, such music and singing and dancing. "Well, good-bye all!" "Good luck!' ' and off we go ashore and walk through the busy little town, busy even then, people hurrying to and fro, frame buildings going up, 


\section{Iremintwenteg of $\mathbb{C h i t a g a}$}

board sidewalks going down, new hotels, new churches, new theaters, everything new. Saw and hammer - saw! saw! bang! bang! - look out for the drays! - bright and muddy streets, gaudy-colored calicos, blue and red flannels and striped ticking hanging outside the drygoods stores, bar-rooms, real-estate offices, attorneys-at-law,-oceans of them!

And now for the new theater! Newly painted canvas, tack-hammer at work on stuffed seats in the dress circle, planing boards in the pit, new drop curtain let down for inspection, - "beautiful!" - a medallion of Shakspere, suffering from a severe pain in his stomach, over the center, with "One touch of nature makes the whole world kin" written under him, and a large, painted, brick-red drapery looped up by Justice, with sword and scales, showing an arena with a large number of gladiators hacking away at one another in the distance to a delightful Roman public; though what Justice had to do with lieeping these gladiators on exhibition was never clearly explained by the artist. There were two private boxes with little white-and-gold balustrades and turkey-red curtains; over one box a portrait of Beethoven and over the other a portrait of Handel-upon unfriendly terms, glaring at each other. The dome was pale blue, with pink-and-white clouds, on which reposed four ungraceful ballet girls representing the seasons, and apparently dropping flowers, 


\section{Ioseph $\mathfrak{I}$ efferson, OThitagoan}

snow and grapes into the pit. Over each season there floated four fat little cherubim "in various stages of spinal curvature."

My father, being a scenic artist himself, was naturally disposed to be critical, and when the painter asked his opinion of the dome, he replied:

"'Well, since you asked me, don't you think that your angels are a little stiff in their attitudes?",

"No, sir; not for angels. When I deal with mythological subjects I never put my figures in natural attitudes; it would be inharmonious. A natural angel would be out of keeping with the rest of the work."

To which my father replied that it was quite likely that such would be the case. "But why have you made Handel and Beethoven frown at each other? They are not mythological subjects."

"No, no," said the painter. "But they are musicians, you know; and great musicians always quarrel, eh? Ha ha!"'

"Yes," said my father; "but as Handel died before Beethoven was born, I don't see how any coolness could have existed between them."

The foregoing dialogue, while it may not be verbatim, is at least in the spirit of the original. I could not possibly remember the exact words of the different conversations that will naturally occur through these chapters; but I have placed 


\section{fimmingetute of oritago}

them in their present form, as I believe it is the clearest and most effective way to tell the story. Many of the conversations and inciclents are traditional in my family; I have good reason to take them for granted, and I must ask the reader to share my confidence.

The greenroom was a perfect gem, with a three-foot wavy mirror and cushioned seats around the wall-traps under the stage so convenient that Ophelia could walk from her grave to her dressing-room with perfect ease.

With what delight the actors lookech forward to the opening of a new theater in a new town, where clramatic entertainments were still unknown-repairing their wardrobes, studying their new parts, and speculating on the laurels that were to be won!

After a short season in Chicago, with the varying success which in those days always attended the drama, the company went to Galena for a short season, traveling in open wagons over the prairie. Our seats were the trunks that contained the wardrobe-those oldfashioned hair trunks of a mottled and spotted character made from the skins of defunct circus horses: "To what base uses we may return!" These smooth hair trunks, with geometrical problems in brass tacks ornamenting their surfaces, would have made slippery seats even on a macadamized road, so one may imagine the difficulty we had in holding on while jolting over a rough prairie. Nothing short of a severe 


\section{Fołeph Feffergon, Chitagaan}

pressure on the brass tacks and a convulsive grip on the handles could have kept us in position; and whenever a treacherous handle gave way our company was for the time being just one nember short. As we were not an express mall-train, of course we were allowed more than twenty minutes for refreshments. We stopped at farmhouses on the way for this uncertain necessity, and they were far apart. If the roads were heavy and the horses jaded, those actors who had tender hearts and tough limbs jumped out and walked to ease the poor brutes. Often I have seen my father trudging along ahead of the wagon, smoking his pipe, and $I$ have no doubt thinking of the large fortune he was going to make in the next town, now and then looking back with his light blue eyes, giving my mother a cheerful nod which plainly said: "I'm all right. This is splendid; nothing could be finer." If it rained he was glad it was not snowing; if it snowed he was thankful it was not raining. This contented nature was his only inheritance; but it was better than a fortune made in Galena or anywhere else, for nothing could rob him of it.

We traxeled from Galena to Dubuque on the frozen river in sleighs-smoother work than the roughly rutted roads of the prairie; but it was a perilous journey, for a warm spell had set in and made the ice sloppy and unsafe. We would sometimes hear it crack and see it bend under our horses' feet: now a long-drawn 


\section{fremintgenteg of Chitago}

breath of relief as we passed some dangerous spot, then a convulsive grasping of our nearest companion as the ice groaned and shook beneath us. Well, the passengers arrived safe, but, horror to relate! the sleigh containing the baggage, private and public, with the scenery and properties, green curtain and drop, broke through the ice and tumbled into the Mississippi. My poor mother was in tears, but my father was in high spirits at his good luck, as he called it-because there was a sandbar where the sleigh went in! So the things were saved at last, though in a forlorn condition. The opening had to be delayed in order to dry the wardrobe and smooth the scenery.

The halls of the hotel were strung with clothes-lines, and the costumes of all nations festooned the doors of the bedrooms, so that when an unsuspicious boarder came out suddenly into the entry he was likely to run his head into a damp "Roman" skirt, or perhaps have the legs of a soaking pair of rect tights dangling round his neck. Mildew filled the air. The gilded pasteboard helmets fared the worst. They had succumbed to the softening influences of the Mississippi, and were as battered and out of shape as if they had gone through the pass of Thermopyla. Limp leggins of scale armour hung wet and dejected from the lines; low-spirited cocked hats were piled up in the corner; rough-chied court coats 


\section{Fałeph Feffergon, Ghicagaan}

stretched their arms out as if in the agony of drowning, as though they would say, "Help me, Cassius, or I sink.'” Theatrical scenery at its best looks pale and shabby in the daytime, but a well-worn set after a six-hours' bath in a river presents the most wobegone appearance that can well be imagined; the sky and water of the marine had so mingled with each other that the horizon line had quite disappeared. My father had painted the scenery, and he was not a little crestfallen as he looked upon the ruins; a wood scene had amalgamated with a Roman street painted on the back of it, and had so run into stains and winding streaks that he said it looked like a large map of South America; and pointing out the Andes with his cane, he humorously traced the Amazon to its source. Of course this mishap on the river delayed the opening for a week. In the meantime the scenery had to be repainted and the wardrobe put in order; many of the things were ruined, and the helmets defied repair.

After a short and, I think, a good season at Dubuque, we traveled along the river to the different towns just springing up in the WestBurlington, Quincy, Peoria, Pekin and Springfield. In those primitive days, I need scarcely say, we were often put to severe shifts for a theater.

In Quincy the courthouse was fitted up, and it answered admirably. In one town a large warehouse was utilized, but in Pekin we 


\section{fremintstenteg of $\mathbb{C h i t a t g}$}

were reduced to the dire necessity of acting in a pork-house. This establishment was a large frame building, stilted up on piles about two feet from the ground, and situated in the open prairie just at the edge of the town. The pigs were banished from their comfortable quarters, and left to browse about on the common during the day, taking shelter under their former abode in the evening. After undergoing some slight repairs in the roof, and submitting to a thorough scouring and whitewashing, the building presented quite a respectable appearance. The opening play was "Clari, the Maid of Milan." This drama was written by John Howard Payne, and his song of "Home, Sweet Home" belongs to the play. My mother, on this occasion, played the part of Clariand sang the touching ballad.

Now it is a pretty well established fact in theatrical history that if an infant has been smuggled into the theater under the shawl of its fond mother, however dormant it may have been during the unimportant scenes of the play, no sooner is an interesting point arrived at, where the most perfect stillness is required, than the "dear little innocent" will break forth into lamentation loud and deep. On this occasion no youthful humanity disturbed the peace, but the "animal kingdom," in the shape of the banished pigs, asserted its right to a public hearing. As soon as the song of "Home, Sweet Home" commenced they began 


\section{Foweph $\mathfrak{F e f f e r g o n ,}$ Uhitagoan}

by bumping their backs up against the beams, keeping anything but good time to the music; and as my mother plaintively chanted the theme "Sweet, Sweet Home," realizing their own cruel exile, the pigs squealed most dismally. Of course the song was ruined, and my mother was in tears at the failure. My father, however, consoled her by saying that though the grunting was not quite in harmony with the music, it was in perfect sympathy with the sentiment.

Springfield being the capital of Illinois, it was determined to devote the entire season to the entertainment of the members of the legislature. Having made money for several weeks previous to our arrival here, the management resolved to hire a lot and build a theater. This sounds like a large undertaking, and perhaps with their limited means it was a rash step. I fancy that my father rather shrunk from this bold enterprise, but the senior partner (McKenzie) was made of sterner stuff, and, his energy being quite equal to his ambition, the ground was broken and the temple erected.

The building of a theater in those days did not require the amount of capital that it cloes now. Folding opera-chairs were unknown. Gas was an occult mystery, not yet acknowleged as a fact by the unscientific world in the West; a second-class quality of sperm-oil was the height of any manager's ambition. The footlights of the best theaters in the western 


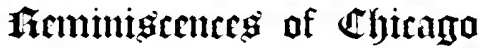

country were composed of lamps set in a "float" with the counter-weights. When a dark stage was required, or the lamps needed trimming or refilling, this mechanical contrivance was made to sink under the stage. I believe if the theater, or "Devil's workshop," as it was sometimes called, had suddenly been illuminated with the same material now in use, its enemies would have declared that the light was furnished from the "Old Boy's" private gasometer.

The new theater, when completed, was about ninety feet deep and forty feet wide. No attempt was made at ornamentation; and as it was / unpainted, the simple lines of architecture upon which it was constructed gave it the appearance of a large dry-goods box with a roof. I do not think my father, or McKenzie, ever owned anything with a roof until now, so they were naturally proud of their possession.

In the miclst of our rising fortunes a heary blow fell upon us. A religious revival was in progress at the time, and the fathers of the church not only launclied forth against us in their sermons, but by some political manouvre got the city to pass a new law enjoining a heavy license against our "unholy" calling; I forget the amount, but it was large enough to be prohibitory. Here was a terrible conclition of affairs: all our available funds invested, the legislature in session, the town full of people, 


\section{Tałeph Feffergon, $\mathbb{T h i r a g a n}$}

and we by a heavy license denied the privilege of opening the new theater!

In the midst of our trouble a young lawyer called on the managers. He had heard of the injustice, and offered, if they would place the matter in his hands, to have the license taken off, declaring that he only desired to see fair play, and he would accept no fee whether he failed or succeeded. The case was brought up before the council. The young lawyer began his harangue. He handled the subject with tact, skill and humor, tracing the history of the drama from the time when Thespis acted in a cart to the stage of to-day. He illustrated his speech with a number of anecdotes, and and kept the council in a roar of laughter; his good-humor prevailed, and the exorbitant tax was taken off.

This young lawyer was very popular in Springfield, and was honored and beloved by all who knew him, and after the time of which I write he beld rather an important position in the government of the United States. He now lies buried near Springfield, under a monument commemorating his greatness and his virtuesand his name was Abraham Lincoln! 



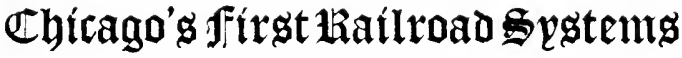

[Reprinted from Andraes's “History of Chicago."]

T $\mathrm{T}$ took many years for the people of Illinois to decide that the proper highway over which the wealth of the Northwest was to pass should be a combination of lake and railroad, rather than of lake, canal and river. The river towns had, since the first settlement, enjoyed a monopoly of the public favor, and even for some time after a few railroads had been chartered, these proposed highways seemed to push toward the river and to promise most of their benefits to the river sections. St. Louis, especially, which had for many years enjoyed a large river trade, was looking for still greater commercial supremacy, whether the rich state to the east should decide to throw its energies into the improvement of the Illinois \& Michigan Canal or into the development of a grand railway system. The handiwork of this wealthy Missouri town is early seen in the legislative proceedings of Illinois. The first movement of this state looking toward the construction of a railway was an act passed in January, I83 I, authorizing a survey from the bluffs of St. Clair County, along the American bottom, to the Mississippi River, near St. Louis. Commissioners were 


\section{Iteminigetuteg of $\mathbb{C h i t a g a}$}

appointed for this purpose. At the same session the commissioners of the Illinois \& Michigan Canal were to ascertain whether a railroad or a canal would be preferable between the Chicago and Desplaines rivers. A canal was deemed more desirable. Even the plank roads through Illinois seemed to be naturally tending toward the great river town. Already a state road had been built from Vincennes, Indiana, to St. Louis, and was much traveled. In 1832 the Springfield \& Alton Turnpike road was incorporated, its river terminus to be in St. Clair County, opposite St. Louis. Chicago was, however, early alive to the necessity of constructing a system of railways which should cut the many ties then binding her own legitimate territory to her old rival.

There was yet another candidate for commercial supremacy in the field, and the state was for some time undetermined as to whether the harbor and canal of Chicago would tend to develop this city into a greater business center than the lead mines would the village of Galena. As previously remarked, the friends of Chicago saw the necessity of doing something to bring her naturally tributary territory into close communication with herself, and, also, by some system which should not pour a flood of advantages into the rich eity which sat by the river, waiting to be macle wealthier. The agitation of a great central railroad through the state therefore commenced, which was to be 


\section{firgit Ifailrond Spgtemg}

operated in connection with the Illinois \& Michigan Canal, and to strike the southern border of Illinois, at or near the junction of the Ohio and Mississippi rivers, there to connect with the railway system of the South. The Illinois Central Railroad may be called the first great "St. Louis cut-off," and as such placed Chicago firmly upon her throne as the magnificent Queen of the West. The preface to this triumphant undertaking was the introduction of a bill in the state senate, in 1832 , by Lieutenant-Governor A. M. Jenkins, for the survey of a central railroad from Cairo to Peru. But public opinion had not yet been molded to see its necessity, and there the project rested. In 1834 the Chicago and Vincennes Railroad was incorporated, but the work was not commenced for many years thereafter. Interest in the central railroad was revived by an enthusiastic letter, which appeared in the public prints, written by Sidney Breese, circuit judge, afterward judge of the state supreme court, and United States senator. It is as follows:

\section{VANDAL1A, October 16,1835 .}

John T. SAwYER, EsQ.

Dear Sir,-Having some leisure from the labors of my circuit, I am induced to devote a portion of it in giving to the public a plan, the outline of which was suggested to me by an intelligent friend in Bond County a few days since (Mr. Waite of Greenville), by which the North may get their long-wished-for canal, and the southern and interior counties a 


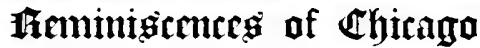

channel of communication quite as essential to their prosperity. In doing so, I have not stopped to inquire if my motives may not be assailed, and myself subjected to unkind remarks, believing, as I do, that the subject is of so much importance as to throw all personal considerations into the shade. The plan then is this: At the junction of the canal with the Illinois River let a railroad be constructed, to extend to the confluence of the Ohio and Mississippi, following, as near as may be, the third principal meridian, and let the credit of the state be pledged for the funds necessary to complete both works. This would be doing equal and impartial justice to three of the most prominent portions of our state, and would create a unity of effort and concert of action that would overcome every obstacle. The general government also would grant some of the unappropriated land on the contemplated road throughout its whole extent in aid of the undertaking, and that it can be accomplished with the means we can raise there can be no manner of doubt. When made, its benefits will be incalculable. It will make the southern and interior counties, cause them to settle, raise the value of their lands (which are intrinsically as good as any), and furnish the means of transportation for their products either to a northern or southern market, of which they are now destitute. It is a stupendous project, but one so easy of accomplishment, so just, so equal, and so well calculated to revive the drooping energies of the South and of the interior, that no doubt can be entertained, if our effort is made at the approaching session of the legislature, but that the canal and the road will be under contract in less than six months after the loan is authorized.

No sectional objections can operate successfully against the project, nor will the people complain of a loan the benefits of which are to be so general and so important. Posterity will have no cause of complaint if we do leave them a debt to pay, when 


\section{firgt Aairroad Spgteng}

at the same time we leave them the most ample means for discharging it. These things have not been regarded in the proper light. No objection should ever be made to incurring such debts when the fund is left out of which to pay them. As well might the heir object to taking his estate of half a million because encumbered by a mortgage of two hundred thousand dollars. By a united, zealous effort at the next session, an artificial artery through the heart of our state, the fairest and richest in the Union, can be made, which will not be surpassed by the stupendous achievements of a similar kind in the other and older states. To avoid jealousies and heartburnings, let the expenditures on both works commence at the same time and be prosecuted with equal energy, and, when this main artery is finished, it will not be long before smaller ones branching off to the Wabash and Upper Mississippi will be constructed. Then Illinois will rival any other state of our vast confederacy, not excepting even that which is so proudly, yet so justly, styled the "Empire State."

To ascertain the interests that can be brought to bear in its favor, take a map of the state and trace upon it the proposed route, and notice the many important and flourishing counties and towns it will pass through and which it will benefit.

Assuming Utica or Ottawa as the point at which the canal will terminate, the mouth of the Ohio bears from it some few miles west. To reach it, the road would pass through La Salle, McLean, Macon, a part of Shelby, Fayette, a part of Bond, Clinton, Washington, Perry, Jackson, Union, and terminate as above in Alexander County. Pursuing nearly a direct line, it would pass through Bloomington, Decatur and Vandalia, where it would intersect the National Road, Carlyle, New Nashville, Pinckneyville, Brownsville, Jonesboro,-all seats of justice of the counties in which they are situate. Along the whole route, especially on the southern portion 


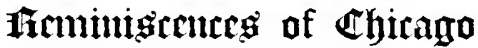

of it, abundant materials of the best kind can be had to construct the work. The distance from one extrenie to the other, on a straight line, is only three hundred miles, and the necessary deviations from that course will not make it more than three hundred and fifty miles. Three fourths of it (that is to say, from Utica or Ottawa to Pinckneyville, in Perry County), the surface of the country, so far as you can determine by the eye, is level or undulating; the remainder is hilly, but by no means mountainous.

Taking the estimated cost of the Alton \& Springfield road as data (which is on an average a fraction over $\$ 7,000$ per mile), the cost of this will not exceed $\$ 2,500,000$, a sum insignificant indeed when we consider the immense benefits to ourselves and to posterity that must flow from its expenditure for such an object. Allowing fifteen miles an hour as the maximum of speed upon it, a locomotive with its train of cars can kindle its fire at Ottawa in the morning and on the next rekindle it at the junction of the Ohio. From this point an uninterrupted communication exists at all seasons with every part of the world, and when the canal and the lakes of the North are locked up by ice the markets of the South can be reached with certainty and speed by the railway and the Mississippi. Let then the South, the interior, and the North unite-let the project be submitted at the coming session, let the loan be authorized, and let us all enter upon it with that determined spirit which should characterize all great undertakings, and success is certain. They who shall be instrumental in its commencement and completion will have erected for themselves a monument more durable than marble, and throughout all future time will receive, as they well deserve, the grateful thanks of a generous people. I hope some gentlemen may feel sufficient interest in this matter to consicler it maturely and give the result of their deliberations to the public through the newspapers. 


\section{firgt Mailrond Spytemg}

It is a great, magnificent and feasible project. It can, it will, be accomplished.

I am, sir, very respectfully your obedient servant, SIDNEY BREESE.

This able letter renewed the waning interest in railroad matters. Meetings were held throughout the state, conventions pronounced in favor of railroad and canal building, and as a result the files of the legislature were literally weighed down with bills and notices of bills to provide for railroad and canal construction.

Many opposed the enterprise in the central part of the state, because it was seen that such a north-and-south line would divert much of the traffic which that section might derive from a road crossing Illinois from east to west. Some localities were pledged to the support of the Wabash \& Mississippi. The line of road as traced in Judge Breese's letter did not touch Springfield, and therefore was not looked upon with great favor by the citizens of that place. Those also who were most ardent in their support of the Illinois \& Michigan Canal feared that its construction would be delayed by the prosecution of this "stupendous project." But Judge Breese never tired in his efforts to acquaint the people living along the proposed route of the road with the advantages of this central artery. He was the prime agent in obtaining the support of Senator Douglas. Chicago also was stretching her arms out 


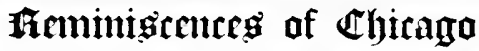

toward the South and the West. "Internal improvement" was the cry of everyone. With the meeting of the legislature at Vandalia, in I 836 , came also the convention which proposed wilder schemes (for those times) than the "internal improvement" act, which became a law the next year. And the people and the press were with the convention, for, under the plans proposed, there was not a "cross-road" in the state which would not in some way be benefited.

The first railroad chartered out of Chicago, upon which work was immediately commenced, and which afterward became an important section of her great transportation system, was the Galena \& Chicago Union Railroad, which was chartered January I6, I 836 . The document was prepared by Ebenezer Peck and $T$. W. Smith, with the object of increasing the value of real estate at both points; but Galena being then the leading village of the West, obtained precedence in the naming of the road. The capital stock was placed at \$IOO,OOO, but could be increased to $\$ 1,000,000$, and the incorporators were given the choice of operating the road by animal or steam power. They were allowed three years from January 16 , I 836, in which to begin work. E. D. Taylor, Jesse B. Thomas, Jr., J. C. Goodhue, Peter Temple, William Bennett, Thomas Drummond and $\mathrm{J}$.W. Turner were named as commissioners to receive subscriptions. The survey of the 


\section{frirgt Itailrand Spgtemg}

road was begun in February, I837, by Engineer James Seymour, with his assistants, from the foot of North Dearborn Street, and ran due west to the Desplaines River. In June, I 837, surveyors and laborers were discharged. In I 838 work was resumed, piles being driven along the line of Madison Street and stringers placed upon them. These operations were continued under the direction of E. K. Hubbard, until the collapse of the enterprise cluring the same year. The ambition of Chicago was evidently a little ahead of her means, and the Galena \& Chicago Union had to wait ten years before it was fairly placed upon a successful basis.

On January I8, I836 (two days after the incorporation of the Galena \& Chicago Union), the Illinois Central was incorporated. The incorporators numbered fifty-eight and they were empowered to construct a railroad from a point on the Ohio to a point on the Illinois, near La Salle, with the object of forming a connection between the canal, then projected, and the Ohio and Mississippi rivers, and thence to the Gulf of Mexico. But the charter and the fifty-eight incorporators failed to accomplish anything in the way of railroad building and the "stupendous project" collapsed, remaining in that lamentable condition until revived by its immense land grant, in September, I 850 .

Up to the latter part of 1837 the only road IOI 


\section{fremintwertuteg of $\mathbb{C l y i r a g a}$}

in the state which had been made a success was the "Coal Mine Bluff Railroad," built by ex-Governor Reynolds and friends, and extending from his coal-fields, six miles from the Mississippi River, to East St. Louis. Among other difficulties overcome by the energetic young men was the bridging of a lake over two thousand feet across. The road was worked without iron, and with horse-power, was regularly chartered in I84I, and long afterward became known as the "Illinois \& St. Louis Railroad." Governor Reynolds' railroad is claimed to be the first one actually constructed in the Mississippi Valley, and, within the circumstances, he appropriately asserts that "it was the greatest work or enterprise ever performed in Illinois. But," he adds, "it well nigh broke us all." And the experience of these pioneers with that little six-mile section of road was the experience of hundreds of other would-be railroad builders, who made more ambitious attempts within the next dozen of years.

But the enthusiasm and the sentiment most prevalent during $1836-37$ are all incorporated in the "Internal Improvement Act" of February 27, I837. The canal was progressing; thirteen hundred and forty miles of railroad were to be built; rivers and creeks were to be rendered navigable, and no less than $\$ 200,000$ were to be distributed throughout the townships of the state, which were doomed 


\section{firgit Hailtoand Spgtemg}

to exist far away from the line of canals, railroads or navigable streams. To prove the magnificence of this legislative dream, the railroads were to be begun at both ends at the same moment; so that the Illinoisans from east and west and from north and south could experience the greatest happiness in their consciousness of the impartiality and wisdom of their legislature.

The act appropriated $\$ 250,000$ to the Great Western Railroad from Vincennes to St. Louis; $\$ 3,500,000$ for a railroad from Cairo to the southern terminus of the canal and to Galena; $\$ 1,600,000$ for a "southern cross railroad" from Alton to Mount Carmel and to Shawneetown; $\$ 1,850,000$ for a "northern cross railroad" from Quincy to Springfield and thence to the Indiana line, in the direction of $\mathrm{La}$ Fayette; $\$ 650,000$ for a branch of the Central road, in the direction of Terre Haute; $\$ 700$,ooo for a railroad from Peoria to Warsaw, on the Mississippi; $\$ 600,000$ from lower Alton to the Central; $\$ 150,000$ for a railroad from Belleville to intersect the Alton and Mount Carmel line; $\$ 350,000$ for a railroad from Bloomington to Mackinaw, and a branch through Tremont to Pekin. The total amount appropriated for railroad building was $\$ 9,650$,ooo. William K. Ackerman, in a paper read before the Chicago Historical Society, February 20,1883 , gives the following extract from the report of Murray McConnel, commissioner, to 


\section{Ifominigenteg of Thicaga}

the fund commissioners, which is dated August I I, I 837 :-

"The kind of iron wanted is of the wilth and thickness that requires twenty-two tons to the mile, including plates, bolts, etc. . . . If you should believe that iron will decline in price so that the same may be bought next year for less than at present, you may contract for the delivery of thirty miles, say six hundred and sixty tons or thereabouts, as we may not want to use more than that quantity in this district through the next season. . . . You will also contract for the building of one locomotive of the most improved plan, and a suitable number of passenger and burthen cars to be shipped via New Orleans to the house of McConnel, Ormsbee \& Co., Naples, Ill.'

"The commissioners' report to Governor Carlin of December 26, 1838, gives the estimated cost of this four hundred and fifty-seven miles of road (which covers only a portion of the present line of the Illinois Central) to be $\$ 3,809,145$, an average cost per mile of $\$ 8,326$. The commissioners, in their report to the governor, say: 'In making these estimates the board has inclucled all the expenditures for superintendence, engineering, and all other incidental expenses. Easy grades have in general been adopted, and in all cases calculations have been made for the most useful and durable structures; and the board has no doubt but that the works may be constructed upon the most approved plans at the cost estimated upon each work. It is believed that in every instance the lines may be improved, locations changed, and improvements made in construction that may lessen the cost far below these prices.' The same piece of road has cost, properly built and equipped as it stands to-day, $\$ 23,950,456$, or an average of $\$ 52,408$ per mile. . . If slight clefects have been found in the law organizing the system, or if errors shall have been committed in carrying it 


\section{firght frailroad Spgitemg}

into execution, it is what might reasonably have been expected in a system so extended. In locating I,300 miles of road and performing other duties equally difficult, it could not well be otherwise than that errors of judgment should occur and that we should be brought into contact with private interests and become the unwilling (though necessary and unavoidable) cause of disappointment to some, and the prostration of splendid but visionary schemes of speculation in others."

Engineer T. B. Ransom, in his report of December 3, I 838, after noticing the progress of work upon the only section of the great system ever completed by the state (a portion of the Northern Cross Railroad), concludes as follows:-

"Believing conscientiously that the future prosperity and happiness of the people will be greatly promoted by carrying out the system to its full and entire completion, I am bound to advocate it to the extent of my abilities. So far from its being too large and extended, I believe that it might be enlarged with great propriety and decided advantage to the general welfare of the whole state (if suitable appropriations were made in addition to those already granted by the legislature), not only to improve the navigation of our rivers, but in connection with the same to drain the ponds and lakes, which can be accomplished with an inconsiderable expense in comparison to the general utility, health and pecuniary prosperity of the whole state.... And it appears to me that even at a period when steamboats are in full operation, the time and risk of life which could be saved by traveling on our roads would enable them effectually to compete with the river communication."

The Northern Cross Road from Meredosia, 


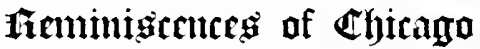

on the Illinois River, to Springfield, was completed in February, I842, the survey having been commenced in May, I837. The road cost the state for actual construction $\$ \mathrm{I}, \mathrm{OOO}, \mathrm{OOO}$, was operated for five years at a loss, and in I 847 realized $\$ 2 \mathrm{I}$, IOO in state indebtedness. The attempt to allay local jealousies by starting the different roads simultaneously from each terminus was one cause of the collapse of the stupendous scheme; as, to clo this, immediate and large appropriations were required. The result was that in two years from the passage of the act the state was checkered with patches of road and had virtually nothing to show for the $\$ 6,000,000$ of indebtedness, except a solitary locomotive running over a few miles of the Northern Cross Road from Mereclosia eastward. The act which had caused all this mischief was repealed in 1839 . Far from lifting every community into an unexampled condition of prosperity, the operations of the law laid the basis of the present debt of the state, and the formal abandonment of the improvements undoubtedly retarded its growth.

Upon the suspension of operations on the Galena \& Chicaro Union Railroad, the people of the Rock River country macle several attempts to arail themselves of Chicago's increasing comnercial importance. First a plank road was urged to be built from Chicago to the Rock River, at a cost of over $\$ 300,000$. 


\section{firght Hailroad Spgtemg}

Next, in I843, a survey was made between Joliet and Aurora for a canal to connect the Fox River with the Illinois \& Michigan Canal; and the suggestion was favorably received that it would be a plausible undertaking to extend the improvements to Rockford. But these schemes were abandoned, and in I846 the Chicago and Galena Union was revived by the convention held at Rockford in January of that year. Delegates to the number of three hundred and nineteen attended from all the counties on the proposed line between Galena and Chicago. The officers selected were: President, Thomas Drummond, of Jo Daviess; vicepresidents, William H. Brown, of Cook, Joel Walker, of Boone, Spooner Ruggles, of Ogle, and Elijah Wilcox, of Kane; secretaries, T. D. Robertson, of Winnebago, J. B. F. Russell, of Cook, and S. P. Hyde, of McHenry. A resolution was adopted that the members of the convention obtain subscriptions to the stock of the company, if satisfactory arrangements could be made with its holders; and resolutions were also passed, presented by J. Young Scammon, showing the necessity of a general subscription to the stock by the farmers along the proposed route. Galena and Chicago vied with each other in the renewed enthusiasm with which the enterprise was taken up. But about this time Messrs. Townsend and Mather offered the improvements, land, and charter of the road, to Chicago citizens for $\$ 20,000$. The 


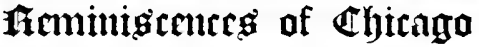

offer was accepted under the following conditions: The payment of the entire sum in fullpaid stock of the company- $\$ 10,000$ immediately after the organization of the board of directors, and $\$ 10,000$ on the completion of the road to Rock River, or as soon as a dividend of six per cent would be earned. On December I 5, I 846, the persons named above subscribed toward the expenses of a survey, and had one made during the succeeding year, by Richard P. Morgan. ${ }^{1}$

The Alton \& Springfield road had been commenced the previous year, and on February 27, I 847, a charter was granted to the Alton \& Sangamon Company, now a portion of the Chicago \& Alton system. On the same day the Rock Island and La Salle line was chartered, the nucleus of the Chicago, Rock Island \& Pacific Railroad Company. The "Pacific" termination of the name was early foreshadowed by the hopeful, public-spirited, and, as it seemed to the more conservative, the "crazy" sentiment of the times. During the legislative session of 1847 the following joint resolution was adopted:-

${ }^{1}$ Richard P. Morgan, who died about two years ago, was one of the oldest civil engineers in the United States, and assisted in laying out many of the principal railroads in the Union. He made the experimental survey of the Galena Air Line road, the first railway emanating from Chicago. At the time of his death he was over ninety-two years of age. 


\section{Firgit Ifailroad Spgtemg}

"Resolved by the House of Representatives of the State of Illinois, the Senate concurring herein, that we have seen and read with pleasure the very interesting report of our worthy and intelligent Senator Breese, upon the proposition of Mr. Whitney, of New York, on the subject of a railroad from Lake Michigan to the Pacific Ocean, and heartily concur in the sentiments and ideas therein set forth.

"Resolved further, that our Senators and Representatives in Congress be, and they are hereby, requested and instructed to use their influence in sustaining the propositions of Mr. Whitney, which have been submitted to the Congress of the United States for a railroad from Lake Michigan to the Pacific Ocean.

"Resolved, that a copy of the above resolutions be transmitted by the Governor of this State to each of our Senators and Representatives in Congress."

Subscription books were opened at settlements along the proposed line of the Galena \& Chicago Union. August I0, I847, William B. Ogden and J. Young Scammon solicited subscriptions in the city, but could only obtain promises for $\$ 20,000$ from all the real estate men or others particularly interested. Some merchants opposed the scheme, fearing it would take the sale of goods from Chicago to points on the line of the road. Up to April I, I848, twelve hundred and six subscribers guaranteed $\$ 351,800$, on which sum payments amounting to $\$ 20,817.68$ were made up to that date. Outside the city there was scarcely any money, and the payment for subscriptions beyond the first instalment of two and one half per cent had to depend upon future crops. 


\section{fimmintents of Ehitago}

The people subscribed as liberally as their limited means would permit, and succeeded in raising a fair amount. Railroad meetings were not frequent in those days, the settlers residing so far apart that they could not assemble on short notice, and those interested in placing the stock were obliged to travel the county to secure its taking. In many settlements the residents were found willing to co-operate, the ladies vieing with the men in their readiness to render assistance. They appreciated how necessary it was to have the road built, and were prepared to make any personal sacrifice to further the undertaking. Many of them helped to pay for the stock subscribed for at their solicitation from the profits derived from the sale of butter, cheese, and other household productions, even depriving themselves of the means required to educate their children, that a railroad might be built for the good of that and future generations.

In the first annual report of the Galena \& Chicago Union Railroad Company, clated April 5, I848, William B. Ogden, the president, saicl:-

"The Michigan Central Railroad Company decided to terminate their road at New Buffalo in July last, and steps were taken preparing the way for an extension of their road to Chicago about the same time. Upon this, your directors proceeded at once to announce their intention of opening books of subscription to stock, for extension of this continous line of railroad from Chicago westward to Galena. 


\section{firit Ifailraad Spgtemg}

Books were accordingly opened at Chicago and Galena, and at the towns intermediate, on the Ioth day of August last and about $\$ 250,000$ of stock were then subscribed. The first expectation of the board was to obtain a general subscription from the citizens of northern Illinois and southern Wisconsin residing along the line of the contemplated road and in its vicinity, as indicative of their faith in the profitable character of the roads when constructed, and of the general interest of the people in its construction; and with the aid of this subscription, to open negotiations with and solicit other subscriptions or loans from Eastern capitalists, sufficient in amount to justify the commencement of the work. The amount subscribed, however, on the opening of the books, was so liberal, and the feeling manifested along the line so ardent and so universal, that it was quite apparent the country and the people immediately interested in the construction of the road, were able to, and would, increase their subscriptions to an amount sufficient, in connection with the credits on iron and engines then offered us, to build the road from Chicago to Elgin at once, and own it ourselves. Experienced parties at the East, largely interested in railroad stock, and decidedly friendly to the success of the Galena \& Chicago road, were consulted and made acquainted with the particulars of our position at this juncture, and with the proposed plan of obtaining the additional means at the East necessary to secure completion of the road to Fox River. They were clearly and decidedly of the opinion that the wisest and surest way to accomplish the speedy extension and completion of the entire route to Galena was for the inhabitants along the line of the road to raise means themselves for its commencement and completion to the Fox River and Elgin, forty-one miles, when there was everything to assure us that the comparatively small cost of construction and extreme productiveness of the country tributary to the road would secure such 


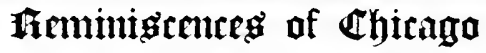

large returns as would enable us to command capital from any quarter, or loans or increased subscriptions to stock for the extension of the road to Rock Island, and to Galena, without delay. This course was aclopted, the object explained and approved by subscribers, and further subscriptions solicited and obtained on this basis of operation, to an extent exceeding altogether the sum of $\$ 350,000$ (about $\$ 10,000$ of stock subscriptions have since been added) and the work was commenced in earnest. A corps of engineers was then (September last) immediately employed to survey and locate the line from Chicago to the Fox River, and prepare it for letting. The time occupied in doing so has somewhat exceeded what was at first supposed to be necessary, and the road, except the first seven miles, was not prepared for letting until the first of March last, when the grading and bridging of the first thirty-two miles (inclusive grading of the seven miles let last fall) was put under contract, and on very favorable terms, as will appear by reference to the report of the chief engineer.'

Under the provisions of the amended charter of February, I847, the owners of stock met April 5, I 848, and elected the following named directors: William B. Odgen, president; Walter L. Newberry, Charles Walker, James H. Collins, J. Young Scammon, William H. Brown, John B. Turner, Thomas Dyer, Benjamin W. Raymond, George Smith, all of Chicago; Charles S. Hempstead and Thomas Drummond, of Galena; Allen Robbins, of New York. Francis Howe was chosen secretary and Treasurer. Thomas D. Robertson, of Rockford, was elected director aice Allen Robbins, resigned, in April, I849; Dexter A. 


\section{Firgit Ifailtand Spgtemg}

Knowlton, of Freeport, wice J. Young Scammon, resigned in $\mathrm{I} 850$.

The early canvassing along the proposed line of the Galena \& Chicago Union Railroad for subscriptions toward building the road was made by Messrs. Ogden and Scammon, who traveled the whole distance from Chicago to Galena for this purpose, holding meetings and obtaining subscriptions at all considerable places on the route. Subsequently Charles Walker, Isaac N. Arnold, John Locke Scripps, John B. Turner, and others canvassed at points on the line of the road. B. W. Raymond and John B. Turner visited the East in $\mathbf{I} 848$, with the object of securing subscriptions to the stock. Their efforts resulted in the sale of $\$ 15,000$ of stock, and a loan of $\$ 7,000$. This money completed the road across the marsh to the foot of Chicago Hill. Again they purchased two locomotives from the Baldwin works. In the meantime, Mr. Odgen, then a member of the common council, had introduced an ordinance into that body, which was voted down, proposing to grant the right of way to the road from the west into the city on a line with Kinzie Street, with the necessary privileges for constructing tracks, drawbridges, and depots; notwithstanding which, the contract for the first thirty-two miles of road from Chicago was let March I, I 848 , the first sixteen miles to be finished by August I, and the balance by October I, I 848 . 


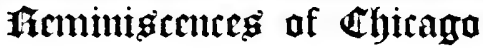

John Van Nortwick had been appointed engineer. George W. Waite, assistant engineer, clrove the first grade-peg, near the corner of Kinzie and Halsted streets, in June, I848, then a point outside the city limits. The council had refused the entrance of the road into the city, but granted leave to build a temporary track east to the river so that one of the two engines could be brought to the head of the road.

In September the management purchased a locomotive of the Tonawanda (N. Y.) Company, and also one of the Auburn \& Syracuse Company. These were fitted up with new gearing and boilers, and the first one was placed on the section between Chicago and the Desplaines River, in November. The "Pioneer" arrived on the brig Buffulo October IO, I 848 . The engine was taken off the boat on Sunday by Rechmond Princleville, Wells Lake, George W. Waite, George C. Morgan and John Ebert, the engineer. This engine was sold by the Baldwin Company on commission for the Rochester \& Tonawanda Railroad Company. It served its purpose well and is in existence to-clay, as if waiting some signal act of public approbation.

When the Desplaines River division was in working order, the rolling stock consisted of six old freight cars and the "Pioneer." By November 2 Ist the engine was running daily on the ten miles of completed road, west of 


\section{firgt Inailraad Spgteng}

Chicago, conveying materials and laborers to carry on the work. The day previous Chicago received the first wheat ever transported by rail. Upon the invitation of the board of directors, a number of stockholders and editors of the city took a "flying trip" over Chicago's system of railways, then extending ten miles west to the Desplaines River! A couple of baggage wagons had been provided with seats, and at about four o'clock P. M. the train, bearing away about one hundred persons, moved from the foot of North Dearborn Street, where a crowd had collected to witness the novel spectacle. On the return trip a load of wheat was transferred from a farmer's wagon to one of the cars, and this was the first grain transported by rail to Chicago. This fact soon became known to the farmers living west of the city, and the company made arrangements to accommodate the expected increase of their business. They at once placed covered cars upon the track, and about a week after the line was open to travel the business men of Chicago were electrified by the announcement that over thirty loads of wheat were at the Desplaines River waiting to be transported to the city. The expected receipts of the road would amount to \$I5 per day for the winter, and wheat-buyers were informed (partly with a view of increasing the passenger traffic) that they must now take their stations at the Desplaines River instead of at Randolph Street 


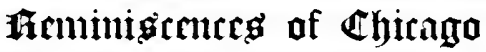

Bridge. Facts and statistics were pouring in from Galena also, showing the benefits that would accrue when the line should reach that flourishing city. For instance, in January, I 849, the public was informed that the arrivals in Galena from March 17 to December 6, I 848, were: Keel-boats, I 58; flat-boats, I07; that the revenue was $\$ 1,950$, and the value of the exports for $\mathrm{I} 848$ was $\$ 1,602,050.40$. Furthermore that "a large portion of these will seek an eastern market by railroad." The citizens of Galena were shoulder to shoulder with Chicago in the building of this road, but rumors were soon afloat that there was a disposition in certain quarters to cut off that thriving town from the benefits of the road which she was doing so much to build. To allay these suspicions, at the annual meeting held April 5, I 849, the stockholders resolved that Galena was the true terminus of the road and that "any diversion would be in violation of good faith, a fraud on the stockholders and an illegal perversion of the charter." Of the \$150,000 loan, authorized in May, I848, to be negotiated, \$7I,700 hat then been expended.

Henry W. Clarke, DeWitt Lane, now of Lane's Island, and Major James Mulford, were the commissioners appointed to procure the right of way for the Galena \& Chicago Union Railroacl, and to assess damages within Cook County. This work was undertaken in March, I 849. The commissioners were accompanied 


\section{firth Haitroad Sopgtemg}

by William B. Odgen, John B, Turner, John Van Nortwick, engineer, James H. Rees, “Ogden's own surveyor," and a few others. When the party reached Harlem, then called Oak Ridge, the commissioners agreed that the assessment of damages for right of way should be merely nominal, and from this agreement resulted the offer of six cents to each land-owner along the route. This offer was accepted without dissent, quit-claim deeds were made to the company, and the roadway was secured.

The inner history of the Galena \& Chicago Union Railroad is most valuable, for the reason that it goes into such details as are not generally given in annual reports. Such facts as a reminiscence could only contain have been fortunately noted down by one who was himself a most important pillar of Chicago enterprise. In J. Young Scammon's biography of William B. Ogden, this history appears to be well and impartially treated; and, therefore, in justice to the men named, is here given so much of that sketch as relates to this road and its builders. 1

"In the winter of 1846 a convention was held at Rockford, the half-way house between Chicago and Galena, to favor the work. There was a large meeting, attended by persons from Galena to Chicago. Thomas Drummond, then residing at Galena, presided over the assembly. The late William H. Brown, always a director and subsequently a president of the Galena Company and of the Chicago Historical

1 Fergus's Series, Biography of William B. Odgen. 


\section{fremintgentes of eritaga}

Society, with Benjamin W. Raymond, our ever publicspirited citizen, and more than once mayor of the city, and a director of the road till it merged in the Northwestern, and who still remains among us to witness and rejoice with others over the success of his faithful public efforts, was among the active men there. Isaac N. Arnold, so long and favorably known in the politics of Illinois, and as a representative in the late War Congress of the United States, and long a leader at the Chicago bar, now president of the Chicago Historical Society and devoting the calm of mature years to literary work, with General Hart L. Stewart, one of Chicago's oldest citizens, whose whole life has been spent in building public works west of Lake Erie, in Michigan, upon the Illinois \& Michigan Canal and elsewhere, and in the public councils of the state or official positions under the government,--rode in the same carriage with the writer, and were active participants in the work of the convention, as was Thomas D. Robertson, of Rockford, for many years a director of the road. We were two days on our journey each way, spending the night at Elgin, then a little hamlet. The landlord there told us that he was against railroads. They were bad things for farmers and hotelkeepers, but good for 'big fellows at the ends of the road.' He 'intended to make money while the road was building and then sell out and go beyond them.' He declared that Elgin would cease to be a place of business as soon as the railroad went beyond it.

"The meeting was harmonious and quite unanimous in its action, the only exception being a tavern-keeper at Marengo, who, fearing that his business would be injured by the road, appeared with his friends in the convention and denounced railroads as 'undemocratic, aristocratic institutions that would ride rough-shod over the people and grind them to powder. The only roads,' said he, 'that the people want are good common or plank roads, upon which everybody can travel.' 


\section{Firgt fiaitroad Spgttmg}

"In the fall of $1847, \mathrm{Mr}$. Ogden and the writer traveled the entire distance from Chicago to Galena together, stopping at all the principal intermediate places, making speeches for the road, and going into the highways to compel men to come in and help the enterprise, even if they could not take more than a single share of stock. Many farmers and other persons, be it said to their credit, did come forward and subscribe, though they had to borrow the first instalment of two dollars and fifty cents on a share and get trusted "till after harvest" for the same. Mr. Ogden was in his element in such enterprises. $\mathrm{His}$ go-aheadativeness here gave full play to his imagination, and filled not only himself, but his hearers, with high hopes and general courage. When it is remembered that it cost five bushels of wheat, and often from four days' to a week's journey to Chicago with a load of grain to get the first instalment of a single or a few shares of stock, none can doubt the public interest in the enterprise.

"At Galena, business men and bankers were fearful of the effect of the railroad upon their town. Among its chief advocates there were Judge Drummond, C. M. Hempstead, Elihu B. Washburne, and Thomas Hoyne. Galena had long been a very prosperous town at the head of navigation on Fever River, and the great lead mining center and mercantile distributor for northwest Illinois and southwest Wisconsin, and the country north in the mines. The great obstacles we met there were two; one, the local effect upon the town, and the other, the fear that before the road should be completed the enterprise would break down, the small stockholders sacrificed, and the road pass into the hands of the large capitalists. We had to meet these objections by the promise to respect and protect the local interests of Galena, to whose capital we were much indebted in starting the work, and a pledge that until the stock rose to par, and was salable at that price, we would never allow the work to proceed faster than its ready means would justify 


\section{fremintwernerg of $\mathfrak{C h i t a g a ~}$}

without endangering the capital invested. This promise was faithfully kept so long as these two persons remained in the directory. It has been said, in justification of the abandoning of the west end of the line to the Illinois Central Railroad, that Galena was doomed, and a different course could not have saved it. The writer dissents from this proposition, and believes that if the pledges Mr. Odgen and he made at Galena had been faithfully, energetically, and courageously carried out, Galena would have been greatly benefited, and its importance and business permanently advanced. But whether this opinion be correct or not, Galena was a pioneer in the work, and the company had no right to sell her birthright to the Illinois Central Company. It would not have been done had the two most active directors, who were among the largest subscribers to the stock when the company was re-organized in the writer's office on the southeast corner of Lake and Clark streets, in the old Saloon Building, in the city of Chicago in 1847 , remained in their position in its management.

"In a paper read before the Chicago Historical Society, by Mr. Arnold, December 20, 1881, on the occasion of the presentation, by Mrs. Ogden, of a portrait of her late husband, it is said 'the officers of the road, after he (Mr. Ogden) had been compelled to retire, had received a public dinner (I think at Elgrin) in which they drank toasts to each other and everybody except Mr. Ogden. The omission of his name, the man who everyone knew had built the road, only made him the more prominent.' If such an occasion took place, the occasion must have been more marked by the absence of the original and most efficient projectors of the road than their presence. There were officers of the road that were engaged in speculating along its line, as was confessed some years later, when one of them was made a scapegoat. Public allusion having been thus made to these personal troubles in the board 


\section{fingit Inailraad Spgtemg}

of directors, it becomes proper to explain the same somewhat, as in doing so a trait in Mr. Ogden's character and conduct presents him in a very bold and advantageous relief, when compared with that of some of his associates. Chicago at that time was a comparatively small and very ambitious city. It had three divisions, occasioned by the river and its North and South branches, which run almost at right angles with the main river, leaving east of them the North and South divisions, and west of them the West division, extending the whole length of the city. Such divisions always create local jealousies, and the selfish interests excited are often difficult to manage or control. Mr. Ogden resided on the north side of the river, as did three other directors, Walter L. Newberry, Thomas Dyer and John B. Turner. Two, Thomas Drummond and Charles M. Hempstead, lived in Galena, and one, Thomas D. Robertson, in Rockford, while the five others, Benjamin W. Raymond, George Smith, Charles Walker, James H. Collins, and J. Young Scammon, lived in the South Division, which was then, as now, the principal business and commercial portion of the town. Mr. Ogden, being especially identified with the North Side, could not exercise as much influence in obtaining subscriptions to stock in the business portion of town as some of the South Side directors, as he was accused by those who never suppose other than solely selfish motives can influence action, of 'wanting to build a railroad that would never pay, to help him sell his lots.' The gentlemen on the North Side naturally desired the road to cross the North Branch, and locate its depots or stations in the North Division; while the West Siders could see no necessity of expending money to cross the river, because the West Side was the largest division of the city and the nearest to the country. In the railroad work, either because Ogden and Scammon had more time to devote to it, or for some other reason, they became the specially 


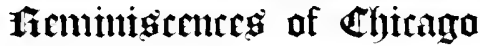

active representatives of the road on their respective sides of the river. The out-of-town directors could rarely attend its meetings, or only when very important questions demanded their presence. These two men gave very much of their time to the enterprise, Mr. Ogden receiving a small salary in stock, and the writer no compensation, except for legal services when required by the board. Ogden and Scammon traveled over the country together, visited Albany and Boston in the interests of the road in company with the late Erastus Corning, then president of the New York Central Railroad and the controlling spirit in the Michigan Central, the only road then in operation west of Lake Erie. They hoped to interest the Boston gentlemen who were stockholders in and engaged in extending the Michigan Central to aid in building the Galena. They called upon the Michigan Central directors, and especially upon William F. Weld, an iron merchant in Boston, who had then the reputation of being 'the Railroad King.' They were very kindly received and entertained by John M. Forbes, then a director of the Michigan Central and a wealthy East India merchant, and long since identified with the Chicago, Burlington and Quincy road, and one of its principal stockholders. Mr. Weld said to us: 'Gentlemen, I do not remember any enterprise of this kind we Boston people have taken hold of upon statistics. You must go home, raise what money you can, expend it upon your road, and when it breaks down, as it surely or in all probability will, come and give it to us and we will take hold of it and complete it, as we are completing the Michigan Central.' A resolution was then formed, though not publicly expressed, that the Galena should not break down. We came home, sought and obtained subscriptions to the stock of the road upon the pledge that the stock should never be endangered until it rose to par, and the holders had an opportunity of selling their shares at that price. This pledge was kept. 


\section{fingt Irailnoad Spgtemg}

“An opportunity occurred, as we were commencing the work, of buying the old strap rail which was being removed from the Rochester \& Canandaigua road, to be replaced with $T$ iron, together with two little second-hand passenger cars and two like engines, for $\$ 150,000$, on a credit of five years, if the writer recollects correctly, provided two of the directors would endorse the bonds. This would require each of the thirteen directors to make himself responsible for a little over one sixth part of that sum as guarantee of the Galena company. There was one director who said 'he never endorsed other people's paper,' and declined to do so, although he was subsequently made president and claimed credit for building the road, with what propriety and how justly, in comparison with the endorsers, let others judge. All the others made the requisite endorsement, with the understanding that we were to stick together and re-elect the old board until these bonds should be paid. We went ahead with the road and had got out west nine or ten miles, across the wet prairie, to the sand ridge, where the teams from the country met us, and transferred their loads to the cars, making the road pay as soon as the first section was completed. We were so encouraged that we thought there ought to be no doubt about raising money to push the work. Mr. Ogden, as president, had boldly made some contracts with McCagg, Reed \& Co., and others, for ties and lumber, based upon expectations of raising money in New York or at the East. A committee, consisting perhaps of Messers. Ogden and Raymond, went to the East for that purpose. They returned unsuccessful. A meeting of the directors was called. It looked blue. To go ahead would endanger the stock. To stop entirely would be a fulfillment of the Railroad King's prophecy. Mr. Ogden was embarrassed. He knew that many of the public had no faith in the railroad, and believed it to be, on his part, an undertaking to aid him in 


\section{Itemintgitcuteg of $\mathbb{C r i t a g o}$}

selling his town lots, they saying that he could well afford to lose his stock if it would help him to sell his land. Most of the other directors were fearful. Mr. Raymond was hopeful, and Walker, Collins, and Scammon, courageous. The latter said he believed arrangements would be made to defer or extend the contracts, and to bridge over the time till the instalments on the stock that would be paid after the harvest should be realized, when the work on the road could proceed slowly, yet successfully. Mr. Dyer, who then owned the Lake House in the North Division, and was very anxious that the work should go on and the road be extencled to the lake, so as to benefit his property, lost faith. The writer called him 'a doubting Thomas.' He replied, 'If Mr. Scanmon has so much faith in the road, I move that a committee of five be appointed, with full power to do anything they deem expedient, in regard to the road, and that Mr. Scammon be chairman of that committee, and be authorized to appoint his associates.' This was agreed to, and a committee, consisting of Mr. Scammon, James H. Collins, Charles Walker, Thomas Dyer, and Mr. Raymond, appointed to have charge of the subject. This committee gave the writer carte lianche. He immediately applied to George Smith, the only banker in the place who could make such a loan, for $\$ 20,000$ for six months, to enable him to go on with the road. Mr. Smith declined, though director of the road, and desirous of sceing it completed. He was asked why - if he had not the money? He replied, 'Yes, but I do not wish to lose it. I have no confidence in the road.' Mr. S. rejoined, 'Don't you think I can build the road to Elgin with the $\$ 363$,000 stock subscriptions we lave of farmers, which are good and sure to be paid?' He answered, 'Yes, but you are not the president of the road.' Mr. Scammon rejoined, 'Don't you think Mr. Ogden can?' Mr. Smith said, 'He can, but he won't,' adding, 'Mr. Scammon, I will lend you the money.' 


\section{firgit frailroad Spgttmg}

The writer replied, 'Nake out your note, and let me have it.' He did so, and the money was taken and placed in the treasury of the company, no other person in the road, except those connected with the loan, knowing from whence it came, except the treasurer, the late Frank Howe. This, with arrangements that were made for extending contracts, enabled the road to meet its engagements, and prevented any suspension of work thereon. The road was pushed and completed to Elgin. It did not cost much money in those days to build a flat railroad on mostly level land. Yet to obtain the small amount necessary required, at that time, more courage and perseverance than is now requisite to build a roacl across the continent. The careful economy exercised in the building of this forty miles was nevertheless very conspicuous. We had money enough only to build the track with very few accessories. It was a single straight line, hardly more. Station houses, sidings, turn-outs and turntables had to be, for the most part, deferred to the future.

"An incident occurs to the writer which may be worth recalling. Upon the completion of the road to Elgin, a general invitation was given for an excursion over the forty miles between Chicago and that place. Among the party was an Irish engineer, who had published, in Dublin, a work on railroad engineering, which he had with him in bright red binding. On alighting from the cars in Chicago, on our return, the writer asked him what he thought of our road. He replied, 'If it is the engineering you're asking about, I don't think anything of it. We would spend more in the old country upon the engineering of a single mile than you have spent upon your entire road.'

"In the meantime rivalries between the west and north sides of the river had sprung up, and some of the North Side directors became suspicious that Mr. Ogden did not want to extend the road across the 


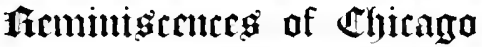

North Branch into the North Division, because his greater interest was on the West Side. The temporary depot was then there. Some of the directors proposed to the writer to accept the presidency of the road. Upon this being declined, it was proposed to make him treasurer and financial agent. This was also declined, for the reason that it would too much interfere with professional work, which the writer was unwilling to give up. Meanwhile, certain officers of the road had been busy misrepresenting Mr. Ogden's actions and intentions to Mr. Scammon and Mr. Scammon's to Mr. Ogden, until the latter was led to believe that there was a conspiracy to turn him out of the presidency and elect the writer in his stead. A counter movement was therefore undertaken by Mr. Ogden and the few who were in his confidence. This movement was not discovered until a few days before the election. Nine of the directors were very much surprised to learn it, and all of these nine sided with the writer. What combinations had been made, and how many proxies were held by the parties in this movement, were unknown. We started for Elgin, where the meeting was to be held. Mr. Ogden's party, with Mr. Arnold as their attorney, went in one car, the other Chicago directors in another. On the way out, the writer said to the directors who were in the car with him, that he had been thinking over the matter, and had come to the conclusion that inasmuch as we did not know how strong the other party were, and what they intended ultimately to do, the better way would be to propose to them that the writer would decline a re-election upon condition that all the other directors should be re-elected without opposition and he said he would name, as his successor, Mr. Knowlton, of Freeport; that the other party would be obliged to accept this, or lose Mr. Knowlton's and the other Freeport votes, which would certainly defeat them; that we coukd not afford to have an open quarrel, which might hurt our credit and embarrass the 


\section{firit Itailrond Spytemg}

progress of the road. The directors with the writer replied, if Mr. Scammon is willing to make this proposition they thought it would succeed, but no one could ask it of him. He replied that he was more interested in the completion and success of the road than in any personal question: that he had worked solely in the interest of the road as a public improvement demanded by the country, and had no selfish axes to grind, and that he would make that proposition, and trust to time for his justification. It was made, much to the surprise of the other party, and after some hesitation or consideration, as it 'broke their slate,' it was accepted. Mr. Ogden was re-elected president; but no sooner was $\mathrm{Mr}$. Scammon out of the directory than all the batteries of the conspirators were turned against Mr. Ogden, and his place was made so uncomfortable that at the end of the year he left the road. Immediately after the election, the nine directors called the conspirators to account; and there was a confession that the writer had been grossly misrepresented and improperly treated, and a promise made that a proper explanation should be made. It was never done. But William B. Ogden acted otherwise. When he learned the facts, and that we had both been made the victims of ambitious and designing men who wished to get rid of the writer, because he had nipped in the bud their first attempt at speculation in the location of the road, and prevented its repetition, and because they knew that they were watched, and so long as he was in the board such movements were likely to be detected and defeated, Mr. Ogden came directly to the writer, and, on learning what statements these parties had made to the latter, relative to Mr. Ogden, at once frankly acknowledged that in his action he had been misled and imposed upon by those he trusted, and that the writer's conduct, to which he had taken so grave exception that he felt justified in self-defense to enter into combination to defeat his re-election, was 


\section{Iftmiltigrenterg of Chiraga}

entirely in the path of right and duty, if the writer believed the representations made to him, as he was bound to do within the circumstances."

The Illinois Central Railroad Company, Judge Breese's stupendous project, which had been lying dormant, but not dead, since the bursting of the internal improvement bubble in 1839, was taken up with renewed energy in I848. John S. Wright, who had early taken a deep interest in public enterprises, and was a man of great foresight, energy and enthusiasm, was actively employed in circulating petitions and documents in favor of a land grant from the general government to assist in the construction of the road, while the father of the enterprise, Judge Breese, was giving his time and energies to it in the Senate of the United States.

Mr. Wright flooded the country with documents laying the matter before every class of people. $\mathrm{He}$ is said to have distributed at his own expense six thousand copies of petitions to Congress for a grant of land in aid of a railroad from the Upper and Lower Mississippi to Chicago. Three different ones were prepared-for the South, Illinois, and the East. Judge Douglas said they came to Washington by the hundreds, numerously signed, and had much influence, being the earliest movement for this object outside of Congress, except by the Cairo Company. Arrangements were then (January, 18.48) being makle to continue the 


\section{JFirgt Whailrand Spgtemg}

Michigan Central Railroad from New Buffalo to Chicago, sixty miles, which, with the road then building across Canada, would connect the city with the east. The Galena \& Chicago Union Railroad had been surveyed. The proposed Buffalo \& Mississippi road via Chicago to the mouth of Rock River was to be extended, in time, to Council Bluffs. An ardent admirer of this project and a warm practical supporter, and a hard worker to make the enterprise a success, was Hon. Stephen A. Douglas. The Illinois Central from Cairo at the mouth of the Mississippi to the canal was designed to be a most important link in the great system of communication between the lakes and the Mississippi, as that river as far south as Cairo was open to the gulf at all seasons of the year.

The original bills, introduced by Judge Breese, as he himself says in a letter to Senator Douglas, published in January, I85 I, did not contemplate a connection with Chicago. They confined the roads to the routes from Cairo, by Vandalia, Shelbyville, Decatur, Bloomington, Peru and Dixon, to Galena. In I 847 Senator Douglas made Chicago his home, and he, in connection with other large property owners, determined to establish a line binding the Northwest with the lakes. Thus many friends were secured for the measure in the northeastern and middle states, who did not favor a proposition having for its natural 


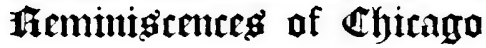

tendency the diversion of trade from the Upper Mississippi toward New Orleans alone. ${ }^{1}$

The bill was reported by Judge Breese, chairman of the committee on public lands, the same year, but did not meet with further consideration.

General James Shields was sent to Congress as the successor of Judge Breese. In December, I 849, Congressman Shields and Senator Douglas, supported by the other Illinois members, prepared the bill, which was introduced into the Senate by Mr. Douglas in January, I850. It passed the Senate May 2, and the House of Representatives September 20, I 850. Its triumph in that body was largely due to the energy and ability of Hon. John Wentworth, the Representative of this district, and the late Governor Bissell, then a member of the House. At the same time a strip of land between La Salle and Cairo, two hundred feet wide, was granted to the state for the uses of road-bed, side-tracks, and stations of the Central Railroad. The main grant, of which this was supplementary, was $2,595,000$ acres in the heart of the state, or alternate sections designated by even numbers for six sections deep on each side of the main line and its branches, and for lands sold or pre-empted within those sections, an equal quantity within fifteen miles on each side of the line, on condi-

${ }^{1}$ See letter from Senator Douglas to Judge Breese, published in Weekly Democrat, March I, I85I. 


\section{firit Thailraad Sygtemg}

tion that the grant would be controlled by Illinois, and when the road should be built would be free to the general government. The minimum price was fixed at $\$ 2.50$ per acre, but in $1852 \$ 5.00$ per acre was realized.

During the previous month, November 5, I 849 , the act to provide for "'a general system of railroad incorporations'" went into effect. It provided that not less than twenty-five persons might form a railroad corporation, and elect directors when $\$ 1,000$ of stock per mile should be subscribed and ten per cent paid in. Thirteen directors were to be chosen, at least seven of whom must reside in the counties through which the road was to run. Rules were laid down for the conduct of the directors, making the stockholders individually liable to the creditors of the company to the amount of stock held by them. Every company before proceeding to construct its road through any county was to make a map of its route and file it in the county clerk's office. The corporation was not to interfere with navigable streams, or obstruct roads and highways. The compensation for any passenger and his ordinary baggage was not to exceed "three cents per mile, unless by special act of the legislature." Rules were also laid down for obtaining the right of way. Each employee was to be appropriately "labeled" with his company's badge. Annual reports were required to be made to the Secretary of State, 


\section{freminterente of $\mathfrak{C h i t a g a ~}$}

and the railroad property listed by the proper officer, the state having a lien upon appurtenances and stock, for penalties, dues and taxes. The act admitted the right of the legislature to alter rates, if the profits were not reduced less than fifteen per cent per annum on the paiclup capital. Three commissioners, appointed by the governor, were to fix the rates of transportation for the United States mail, in case the railroad could not agree with the general government. Should a passenger not pay his fare the conductor was authorized to "put him off." Under no circumstances were freight cars to be placed behind passenger coaches, and at least a thirty-two pound bell or a steam whistle was to be placed on the locomotive, and worked at least eighty rods from a railroad crossing. Penalties were provided for a violation of these sections. "Warning boards" were to be erected, on whicli were to be painted, in capital letters of at least the size of nine inches, "Railroad Crossing-Look out for the cars while the bell rings, or the whistle sounds." This was not to apply to city streets. By act of the general assembly, approved February I7, I85I, an act entitled "An act to incorporate the Great Western Railway Company, " approved March 6, 1843; "An act to amend an act entitled an act to incorporate the Great Western Railway Company," approved February IO, I 849, and "An act to incorporate the Illinois Central 


\section{firgt hailroad Spgtemg}

Railroad Company,' approved January I6, I836, were repealed. By section 3 of the same act the grant of Congress approved September 20, I850, was accepted.

Prior to the passage of this wholesale repealing act, a memorial was presented to the general assembly. It is dated December 28, I 850 , and signed by Robert Schuyler, George Griswold, Gouverneur Morris, of Morrisania, Franklin Haven, David A. Neal, R. Rantoul, Jr., J. Sturges, Thomas W. Ludlow, and John F. A. Sanford. The memorialists offer to build a road from Cairo to Galena, with a branch to Chicago, on or before July 4, I 854 , "as well and thoroughly built as the railroad running from Boston to Albany," agreeing furthermore, in consideration of the charter and the land grant to "pay annually _ per cent of the gross earnings of the said road." The general reader may be glad to learn that this blank was filled with a "seven" and that this agreement became one of the cornerstones of the financial stability of the state of Illinois. ${ }^{1}$

On February Io, I85I, the legislature, declaring that in its judgment the object of incorporating the Central Railroad Company could not be attained under general laws, passed an act incorporating the Illinois Central Railroad Company. The event was celebrated in

${ }^{1}$ The amount thus paid over to the state has been over $\$ 9,000,000$. 


\section{Iteminimenteg of ohtraga}

Chicago by a popular demonstration of favor. The corporators were the memorialists mentioned above, and Henry Grinnell, William $\mathrm{H}$. Aspinwall, Leroy Wiley, and Joseph W. Alsop. These gentlemen, with the governor of the state for the time being, were constituted the first board of directors.

To this company the congressional grant of right of way and public lands, together with "the right of way which the state of Illinois has heretofore obtained"; the lot of land obtained by the state within the city of Cairo for a depot; "all the grading, embankments, excavations, surveys, work, materials, personal property, profiles, plats and papers constructed, procured, furnished and done by or in behalf of the state of Illinois, for or on account of said road and branches, and the right of way over and through lands owned by the state," were "ceded and granted," and the company was required to execute a deed of trust of all this property, together with "the railroad which may be built," to Morris Ketchum, John Moore and Samuel D. Lockwood, trustees, to secure to the state the first lien on the property so conveyed, the construction of the road, and the indemnification of the state against the claims of the United States, in case the road should not be completed within ten years as required by the act of Congress of September 20, I 850 . Thus the magnificent grant to the state was relinquished to a private 


\section{firgit Ifailtrand Sptotemg}

corporation, not without strong opposition, however, for there was a deep feeling against the measure. The magnitude of the grant was so overpowering to the minds of many good citizens that they argued earnestly that by proper management the state might not only build the seven hundred miles of railroad, but from the proceeds of the lands pay off a burdensome state debt of many millions of dollars besides. Doubtless this might have been possible, but the opportunities for "steals" might not have been easily resisted. John S. Wright published a pamphlet in which he insisted that the state would be "everlastingly dishonored if the legislature did not devise laws to build the road, and disenthrall the state of its enormous debt besides, out of the avails of this grant." The company negotiated a loan of $\$ 400,000$, but the money could not be realized until there should be a conveyance of the lands from the general government. In this there was some delay. Justice Butterfield, the commissioner of the general land office at Washington, who was from Chicago, construed the grant as entitling the company to lands for the Chicago branch, on a straight line to Chicago, which would avoid the junction with the Michigan Central. After some vexatious delay this construction of the act was overruled by the President and Secretary of the Interior, and in March, 1852 , the necessary patents were issued, contracts were awarded, 


\section{freminigtenteg of $\mathfrak{C h i t a g a ~}$}

work commenced and the road pushed forward to completion with little interruption.

The successive steps by which the Illinois Central has obtained a property foothold in Chicago commenced with the payment of $\$ 45,000$ to the general government, in October, I $85^{\circ}$, in consideration of which the company obtained possession of the unoccupied portion of the Fort Dearborn reservation. The railroad company paid the sum under protest, claiming that this tract was included in the congressional grant. Suit was brought in the Court of Claims for the recovery of the money, but the decision went against the company. In 1852 the legislature empowered the company to build a branch from the terminus at $T$ welfth Street to the south pier of the inner harbor, and the city council supplemented the action of the legislature in June of the same year by an ordinance permitting the company to lay tracks parallel with the lake shore, the condition being that the road should enter the city at or near the intersection of the southern limits and the lake, and pursue a course along the shore to the southern limit of Lake Park, to front of Canal Section No. I5, and continue due north to the proposed site within the Fort Dearborn adclition to Chicago, between the line of Randolph Street and the main river. This actually handed over to the company the right to use a strip of shore three hundred feet wide, east of a line drawn parallel with Michigan 


\section{firgit frailroad \$ngtemg}

Avenue, four hundred distant from the west line of that thoroughfare.

In September, I852, the Illinois Central commenced work on the lake shore protection, or breakwater, which was completed in two years, under the superintendency of Colonel R. B. Mason, chief engineer.

In 1855 the common council gave the company permission to use a triangular piece of land which lay north of Randolph and a short ciistance west of the land granted in 1852 . In I 856 the city granted a right to use the space between the breakwater, from a point seven hundred feet south of the north line of Randolph Street, branching out and running thence to the southeast corner of the company's breakwater as then established, and thence to the river. In February of this year, passenger trains over the Illinois Central, the Michigan Central, and the Chicago \& St. Louis roads commenced to run into the new depot of the first named company. After that year the company continued to improve and possess submerged and other lands east of the east line of the two hundred feet granted in the original ordinance.

This company was the first to take action in the matter of suburban trains. A time table was issued June I, I 856, and three trains placed on the line between the city and Hyde Park. 




University of California

SOUTHERN REGIONAL LIBRARY FACILITY

405 Hilgard Avenue, Los Angeles, CA 90024-1388

Return this material to the library from which it was borrowed.

Renewed

to

$$
5 / 17
$$




\section{||$_{3}|||||||||||||||||||||| \mid$}

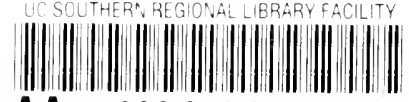

AA 0000192138 


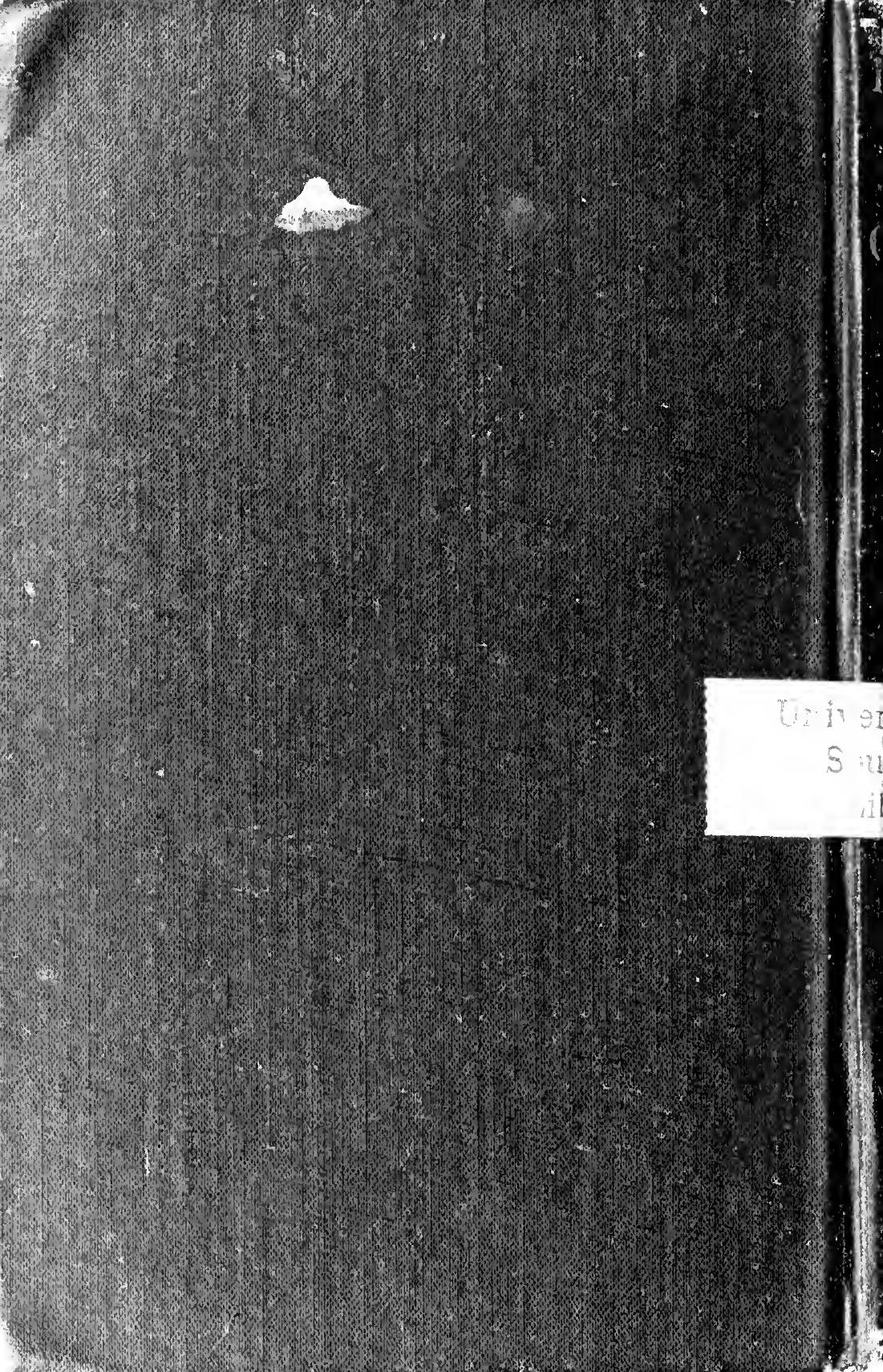

